\title{
Contrasting stress fields on correlating margins of the South Atlantic
}

\author{
Eric Salomon ${ }^{\text {a, } *}$, Daniel Koehn ${ }^{\mathrm{b}}$, Cees Passchier ${ }^{\mathrm{a}}$, Peter Christian Hackspacher ${ }^{\mathrm{c}}$, Ulrich Anton Glasmacher ${ }^{\mathrm{d}}$ \\ ${ }^{a}$ Institut für Geowissenschaften, Johannes Gutenberg-Universität Mainz, Johann-Joachim-Becher Weg 21, 55128 Mainz, Germany \\ b School of Geographical and Earth Sciences, University of Glasgow, Glasgow G12 8QQ, United Kingdom \\ c Instituto de Geociencias e Ciencias Exatas, UNESP, Rio Claro, SP 13506-900, Brazil \\ ${ }^{\mathrm{d}}$ Institute of Earth Sciences, University of Heidelberg, Im Neuenheimer Feld 234, 69120 Heidelberg, Germany
}

\section{A R T I C L E I N F O}

\section{Article history:}

Received 19 March 2014

Received in revised form 18 August 2014

Accepted 2 September 2014

Available online 5 October 2014

Handling Editor: A.R.A. Aitken

\section{Keywords:}

Paleostress

Passive margin

South Atlantic

Namibia

Brazil

\begin{abstract}
A B S T R A C T
The "passiveness" of passive continental margins across the globe is currently under debate since several studies have shown that these margins may experience a variety of stress states and undergo significant vertical movement post-breakup. Of special interest is the South Atlantic, because the bounding continents have very different recent geological histories, with Africa experiencing continental rifting whereas South America is influenced by subduction on the Pacific side. It is not clear to what extent the Atlantic continental margins are subject to the same stresses and vertical motions as the main continents. To address this problem, we performed a paleostress analysis of two originally adjacent areas, i.e. NW Namibia and SE/S Brazil. Both areas are covered by the $~ 133-M a-$ old Paraná-Etendeka extrusives that were emplaced shortly before or during the onset of the Atlantic rifting. Thus, the volcanics serve as a time marker for syn- or post-rift deformation. Collected fault slip data in the volcanics reveal remarkable differences between the two correlating areas. NW Namibia was dominated by extension in ENE-WSW and SW-NE directions, and by minor strike-slip movement with NW-SE directed compression. SE/S Brazil was mostly affected by strike-slip faulting, with compression oriented E-W and SW-NE. Similar fault systems appear widespread across SE Brazil and may be the combined result of flexural margin bending and the Nazca plate subduction. The results of NW Namibia differ from known compressional stress tensors in western South Africa, post-dating $90 \mathrm{Ma}$. The south-western African continental margin may thus have experienced a spatially variable stress history. Our results show that the tectonic evolution of the continental margins of the South Atlantic is not passive and that both margins vary significantly in structural style and stress fields, indicating that variable plate boundary forces play a major role in margin evolution.
\end{abstract}

(c) 2014 International Association for Gondwana Research. Published by Elsevier B.V. All rights reserved.

\section{Introduction}

Rifting of continents and the following continental break-up leads to the development of relatively stable continental margins (McKenzie, 1978). They are generally characterized by listric normal faults, rotated blocks and down-lapping sedimentary sequences. Typical examples can be found along the eastern and western rims of the Atlantic Ocean. In terms of relative vertical motion, the initial rift is characterized by a subsiding graben and adjacent high rift flanks. During break-up, volcanic activity may lead to widespread rock and surface uplift of the whole rift and this is followed by subsidence due to cooling and thermal contraction of the underlying lower lithosphere and asthenosphere. The original rift flanks adjacent to the continental margins are thought to remain at high elevation even though they are subject to considerable erosion. However, this relatively simple history has been challenged by studies that

\footnotetext{
* Corresponding author. Tel.: + 4961313920293.

E-mail addresses: salomon@uni-mainz.de (E. Salomon), daniel.koehn@glasgow.ac.uk (D. Koehn), cpasschi@uni-mainz.de (C. Passchier), phack@rc.unesp.br (P.C. Hackspacher), ulrich.a.glasmacher@geow.uni-heidelberg.de (U.A. Glasmacher).
}

indicate that passive continental margins may be subject to multiple rock and surface uplift and subsidence phases and are thus not completely passive. Examples of margins with such complex uplift histories include the margins of northwest Britain (Stoker et al., 2010) and western Greenland (Bonow et al., 2006). The evolution of the South Atlantic passive continental margins is also currently debated (Karl et al., 2013). These margins have been affected by rifting, hotspot activity and potentially by far field stresses and regional flexural bending. There are significantly different views on how similar or different the continental margins east and west of the South Atlantic behave. Some authors (Cobbold et al., 2001) argue that far field stresses from the Andean orogeny subjected the passive continental margin of Brazil to margin-perpendicular compression throughout the Cenozoic. Others argued that the Brazilian and Namibian margins have been influenced by flexural bending due to sediment loading offshore (e.g., Lima et al., 1997; Dauteuil et al., 2013; Reis et al., 2013). On the eastern margin of the Atlantic upwelling of the African superplume, a large thermal anomaly in the lower mantle beneath southern Africa (e.g., Ritsema et al., 2011 ) is thought to be responsible for the high average topography of southern and eastern Africa (e.g., Lithgow-Bertelloni and Silver, 
1998; Al-Hajri et al., 2009; Moucha and Forte, 2011). Japsen et al. (2012a) favor a model where both continental margins undergo the same multiple uplift events driven by transfer of far field stresses from one continent to another.

An understanding of the behavior of continental margins following continental breakup is vital to our understanding of plate tectonics and the effects of far field stresses across continents. Therefore, we choose to perform a paleostress analysis of NW Namibia and SE/S Brazil, two areas that were connected prior to the opening of the South Atlantic (Figs. 1, 2a). The areas are ideally suited for such a study since they are covered by volcanic rocks of the Paraná-Etendeka Large Igneous Province (Milner et al., 1995), which were emplaced just before or during the onset of the South Atlantic opening (Renne et al., 1992; Torsvik et al., 2009). Furthermore, the study areas are situated at similar distances $(200-250 \mathrm{~km})$ from the continent-ocean boundary (as defined by Torsvik et al., 2009). The paleostress analysis was conducted using measurements on fault planes and striations on faults within the basalts of the Paraná-Etendeka sequence in order to estimate stress fields during or post breakup and thus attain an understanding of the onshore tectonic evolution of both margins.

\section{Geologic setting}

The continental margins of NW Namibia and SE/S Brazil are characterized by low-to-high grade metamorphic basement rocks of Neoproterozoic age (560-530 Ma) forming the Kaoko Belt on the Namibian side and the Dom Feliciano Belt on the Brazilian side, both of which developed during the amalgamation of Gondwana (e.g., Goscombe et al., 2005; Foster et al., 2009; Oyhantçabal et al., 2011; Fig. 1). The present-day continental margins run parallel or sub-parallel to prominent shear zones and the main trends of foliation and lineation in both belts. Where the shear zones are partly covered by overlying rocks, they are thought to maintain their general trend in a NE direction in the Dom Feliciano Belt, based on interpolation (e.g., Chemale et al., 2012) and a N-NNW direction in the Kaoko Belt, based on aeromagnetic data (Corner, 2008).

The basement rocks are overlain by sedimentary rocks of the Karoo (southern Africa) and the Paraná basins (South America). They belong to a set of intracontinental basins which span South America, Africa, Antarctica and Australia (de Wit et al., 1988; Smith et al., 1993). The basin sediments were deposited from the Carboniferous to the Jurassic. The deposits are widely exposed in SE/S Brazil, whereas in NW Namibia they are mainly restricted to the Huab area (Miller, 2008, and references therein; Fig. 2).

The aeolian sandstone of the Botucatu (Brazil) and Twyfelfontein Formations (Namibia) overlies the Karoo/Paraná sedimentary rocks (Fig. 2). The age of these formations is Upper Jurassic to Lower Cretaceous (e.g., Scherer, 2000; Dentzien-Dias et al., 2007; Perea et al., 2009). The Botucatu/Twyfelfontein Formation reaches a thickness of up to $150 \mathrm{~m}$ (Mountney and Howell, 2000) and inter-fingers with the volcanics of the Paraná-Etendeka Large Igneous Province (Jerram et al., 1999), which covers large parts of South America and southern Africa. In Brazil, these extrusives are referred to as the Serra Geral Formation, while in Namibia they are attributed to the Etendeka Group. Today the Serra Geral Formation covers an area of about $1.2 \times 10^{6} \mathrm{~km}^{2}$ (Melfi et al., 1988) with a maximum observed thickness of about $1700 \mathrm{~m}$ (Peate et al., 1990), whereas the Etendeka Group covers about $78.000 \mathrm{~km}^{2}$ in Namibia with a maximum thickness of around $900 \mathrm{~m}$ (Erlank et al., 1984; Milner et al., 1992; Gallagher and Hawkesworth, 1994). The Paraná-Etendeka Large Igneous Province consists of up to 120 lava flows (Hartmann et al., 2012) which vary significantly in chemical composition ranging from basaltic lavas to massive quartz latites (Milner and Ewart, 1989; Milner et al., 1992). A stratigraphic correlation of lavas across the Atlantic was established by Milner et al. (1995). The age of the Large Igneous Province is $133 \pm 1 \mathrm{Ma}$ (Renne et al., 1992) and the eruption period lasted approximately 2.4 million years (Milner et al., 1995). In the northern part of the Brazilian study area, an alkaline intrusion (Lages Volcanic Field) is dated to $76 \mathrm{Ma}$ (Gibson et al., 1999). About $400 \mathrm{~km}$ north of our

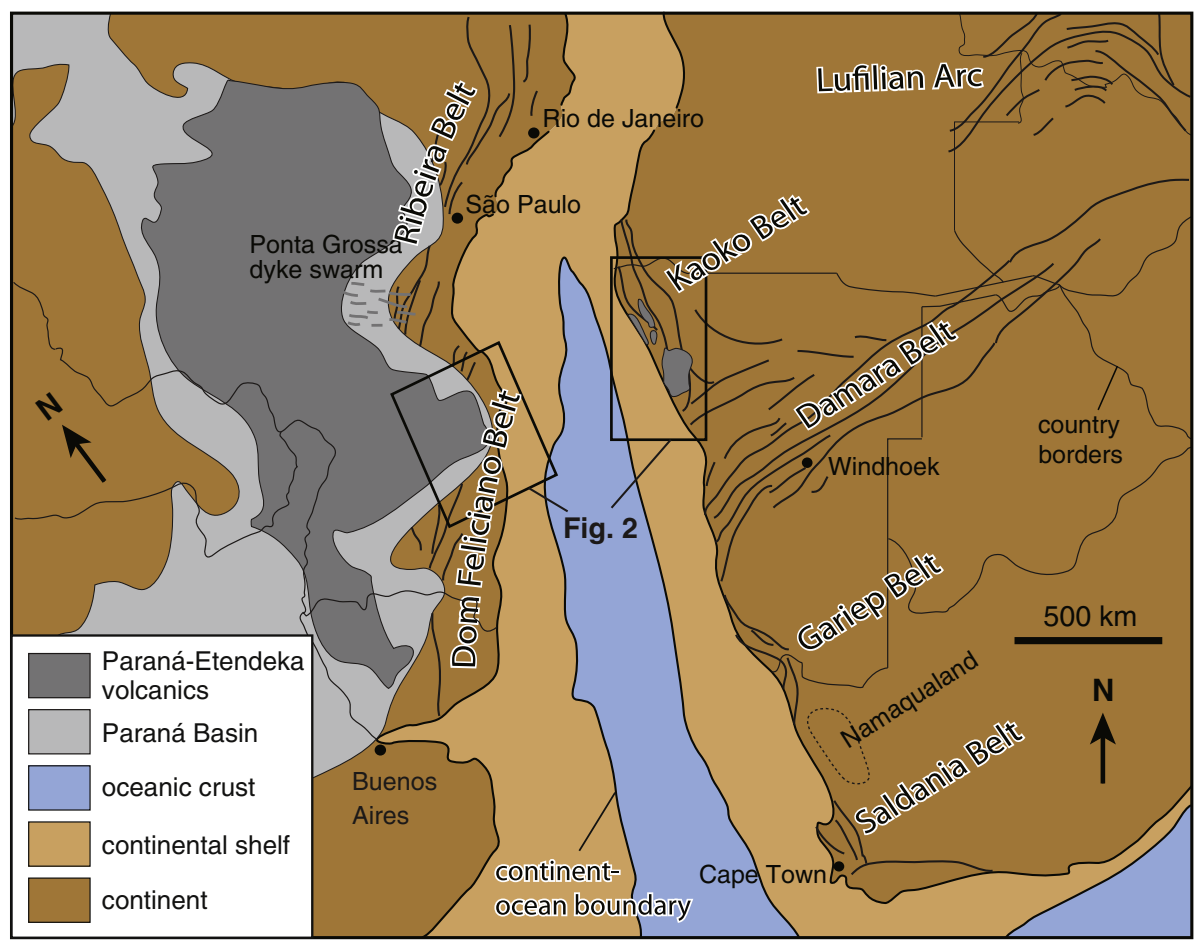

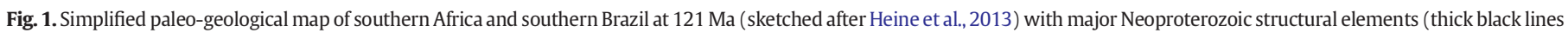
on continents; adopted from de Wit et al., 2008) and sketched present extent of the Paraná Basin and Paraná-Etendeka Large Igneous Province (after Waichel et al., 2012). 

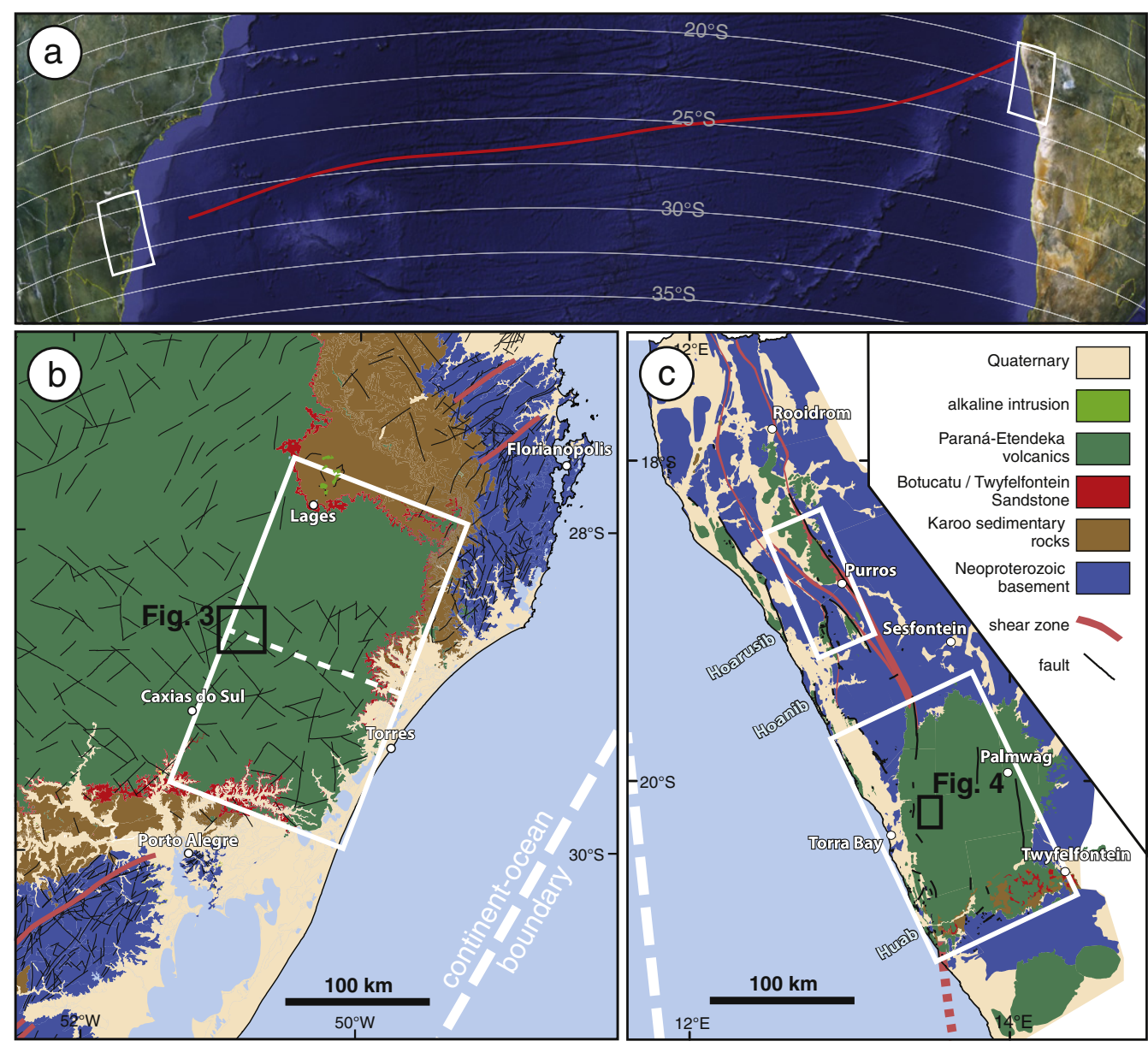

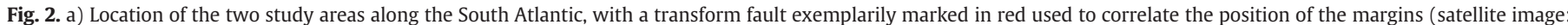

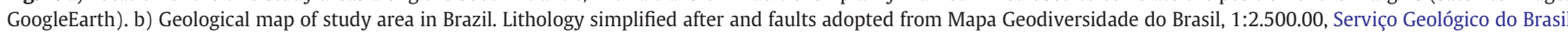

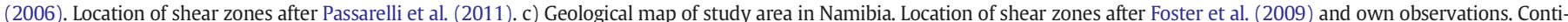

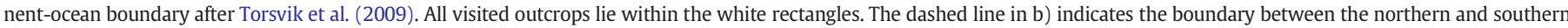
study area in Brazil (see text for further explanation).

Brazilian study area lies the NW-trending Ponta Grossa dyke swarm (Fig. 1) that can be traced for at least $300 \mathrm{~km}$ into the continental interior from the margin (Strugale et al., 2007). The swarm comprises hundreds of dykes and is related to a late phase of the Paraná-Etendeka volcanic extrusion (e.g., Piccirillo et al., 1990; Renne et al., 1996; Deckart et al., 1998).

The volcanics of the Paraná-Etendeka Large Igneous Province were emplaced shortly before or during the onset of the South Atlantic rifting. At this latitude, the oldest magnetic polarity chron in the oceanic crust is identified as M4 (M5n) (Rabinowitz and LaBrecque, 1979; Moulin et al., 2010). For this chron, geomagnetic polarity timescales set an age in the range of 126-130 Ma (126 Ma in Channell et al., 1995; 130 Ma in Gradstein et al., 2004; Tominaga and Sager, 2010; 127 Ma in Malinverno et al., 2012).

Offshore seismic profiles reveal extensive listric normal faulting along both continental margins (Gladczenko et al., 1997; Blaich et al., 2011). Offshore, syn-rift emplacement of basalts is interpreted for both sides of the Atlantic (Bauer et al., 2000; Blaich et al., 2011) and is related to the Paraná-Etendeka extrusives (Beglinger et al., 2012). Other offshore data, however, indicate pre-rift extrusion of the Paraná-Etendeka volcanics (Stica et al., 2014). An Albian rift is situated approximately coast-parallel offshore NW Namibia (Holtar and Forsberg, 2000). In onshore NW Namibia, syn-volcanic normal faulting of the Etendeka Group is reported by Milner and Duncan (1987) and Stollhofen (1999). North of the Brazilian study area between the cities of São Paulo and Rio de Janeiro, the continent was furthermore affected by Cenozoic development of the Continental Rift of Southeastern Brazil. This rift developed during the Paleogene and has continuously been active throughout the Cenozoic including some phases of inversion (e.g., Riccomini, 1989; Ferrari, 2001).

Morphologically both margins differ significantly. Along the Namibian coast the margin is smooth with a trend of $\sim 165^{\circ}$ (SSE), while along SE/S Brazil it trends approximately $210^{\circ}$ (SW) (Torsvik et al., 2009) but has E-W trending right-lateral steps that are visible on bathymetric maps (i.e. GEBCO data on Google Earth, Fig. 2a). These steps are in the prolongation of oceanic fracture zones and regarded as old rift-transfer zones (Stica et al., 2014). Between Florianopolis and Rio de Janeiro, the Brazilian margin is segmented by WNW trending transfer zones (Meisling et al., 2001), which have been reactivated left-laterally in the Neogene (Cobbold et al., 2001; Karl et al., 2013).

\section{Methodology}

Our study is concentrated on the Paraná-Etendeka extrusives and the interfingering Twyfelfontein/Botucatu Sandstone, as these rocks were emplaced during or shortly before the onset of the South Atlantic rifting. All deformation recorded in these lithologies is either related to rifting or post-dates it. Both study areas (Fig. 2) were analyzed using 
existing geological maps, satellite imagery provided by Google Earth, and $30 \mathrm{~m}$-ASTER digital elevation models in order to map lineaments and identify potential faults (Figs. 3, 4). For measuring lineaments, no minimum length was applied and curving lineaments were separated into segments.

Field investigations were carried out to collect fault slip data and to analyze fault relationships. Outcrops were selected by the means of availability, i.e. mostly road cuts and open pits in Brazil, and mostly along incised river valley and mountain shoulders in Namibia. Mechanically formed striations and fiber growth were used as slip indicators (Fig. 5). Cross-cutting relationships were recorded, i.e. faults being cut off by other faults or fiber packages on slickenside surfaces. These criteria help to place stress systems into a relative chronological order. Overprinting between fiber packages however was not used for establishing a chronological order since it is hard to determine their relative age (Sperner and Zweigel, 2010). As fiber growth found on fault planes consisted of quartz and calcite only, we did not use mineral growth as an indicator for subsets or relative timing of subsets. Fiber growth is dependent on fluid flow, which could have (re-)occurred at any time, and mineralogy is dependent on the spatial distribution of quartzitic and/or calcitic rocks hosting the fluid system.

All measurements were corrected for the magnetic declination. In the field, we grouped the collected fault slip data into three categories regarding their quality ( $1=$ excellent, $2=$ good, $3=$ poor $)$, i.e. how well we could see the slip indicators and direction of movement. For the paleostress analysis, we later neglected quality 3 measurements and data with a misfit of more than $10^{\circ}$ between the fault plane and respective slickenside orientation. It is to be noted, that the interpretation of our data does not change significantly if it is restricted to only quality 1 measurements.
The fault slip data were then used to perform a stress inversion for which the following assumptions are necessary:

- Measurements on small outcrop scale faults are representative of regional stresses and local block rotation has not distorted the stress fields significantly.

- The material is homogeneous at large scale so that the fault slip inversion gives the infinitesimal strain tensor, which can be directly linked to the stress tensor.

- The data allow the separation of multiple stress events.

It must be kept in mind, that the linkage of the infinitesimal strain tensor to the stress tensor in particular may be a source of error if the rock is not isotropic. The directions of stress and strain might differ due to reactivation of inherited structures in the rock. Another problem concerns deformation of foliated rocks, in which the stress may only be large enough to produce visible deformation in areas with a favorable foliation orientation.

The data were processed following the "stress inversion via simulation" method developed by Sippel et al. (2009), which combines the PBT-Method (Turner, 1953; Sperner et al., 1993) with the Multiple Inverse Method of Yamaji (2000). The PBT-method calculates the orientation of the principal strain axes for each measured fault. The basis of this calculation is the Mohr-Coulomb fracture criterion, where a fracture plane is created at a certain angle between the normal and shear stress axis (typically $30^{\circ}$ between $\sigma_{1}$ and the fracture plane; e.g., Handin, 1966; Byerlee, 1968; Twiss and Moores, 2007), depending on the cohesion and friction of the specific rock. In return, it is thus possible to calculate the orientation of the principal strain axes for a given fault movement on a newly formed plane. The data that are acquired give the three principal strain directions for each single fault measurement.

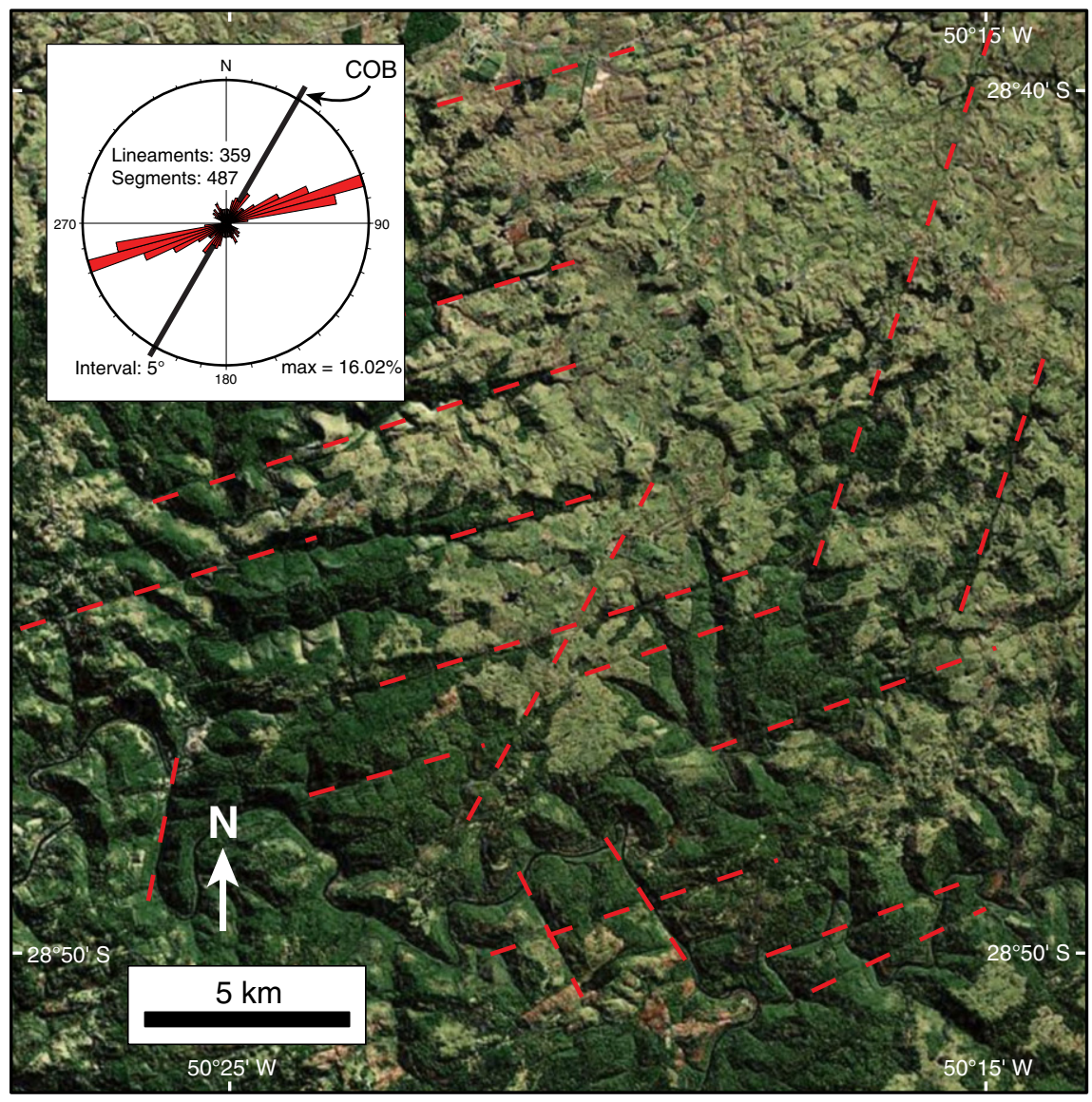

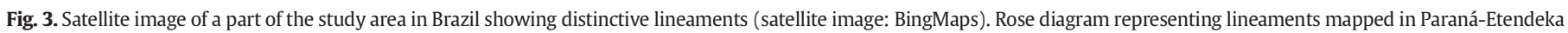
basalts in the SE/S Brazilian study area on satellite imagery. Note that lineament segments are plotted. Lineaments are divided into segments if they are curving. 


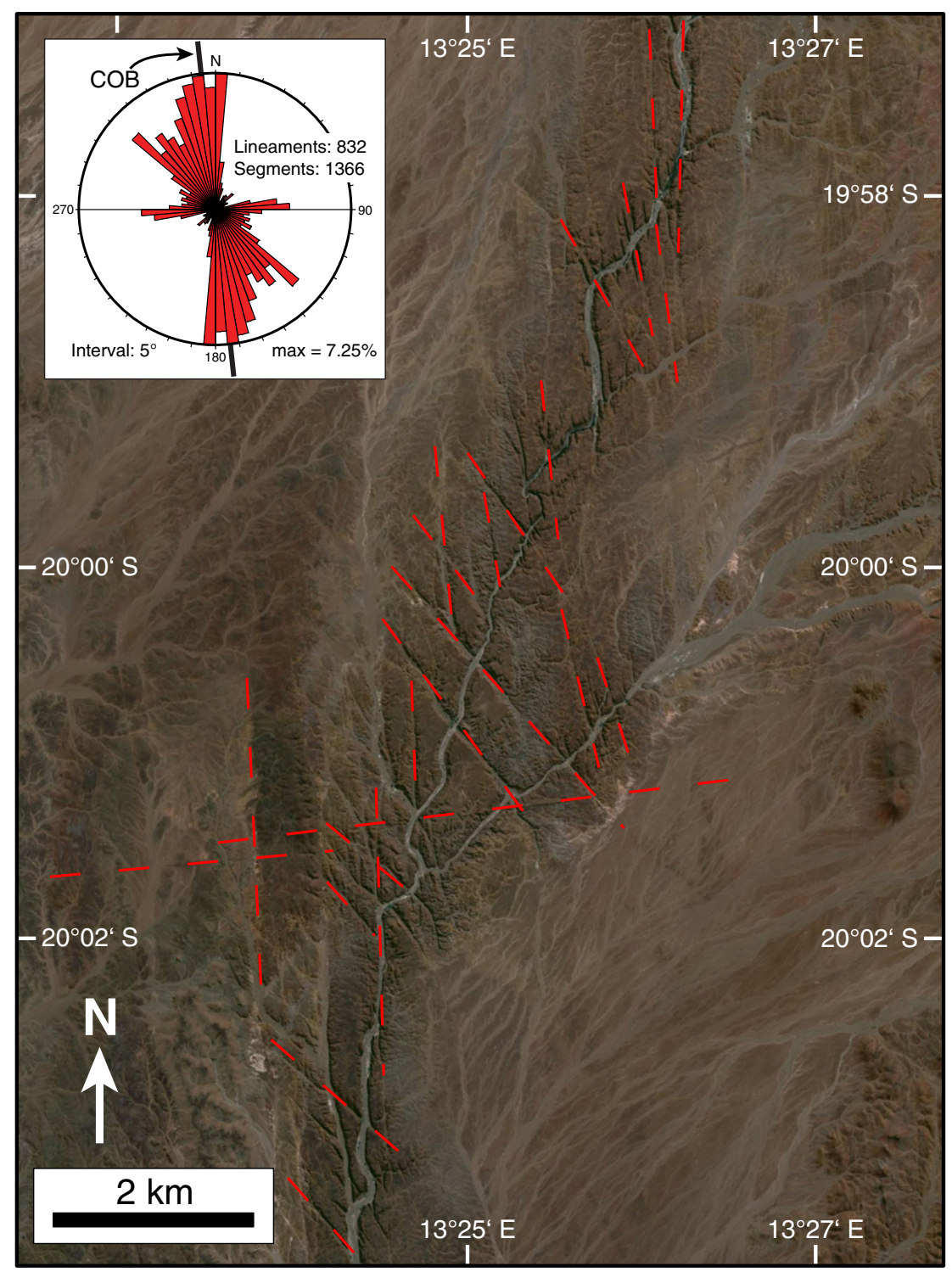

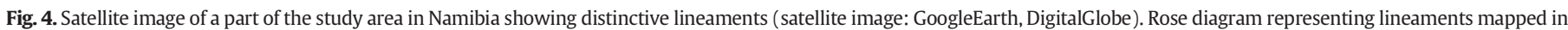
Paraná-Etendeka basalts in the NW Namibian study area on satellite imagery. Note that lineament segments are plotted. Lineaments are divided into segments if they are curving.

In order to attain significant larger scale stress tensors from these single fault plots we are looking for faults with similar strain patterns and thus for clusters of principal strain axes. This is usually first done on a single outcrop basis and then extended to outcrop clusters and larger areas. In a data set that contains several stress histories, one has to identify single stress events with consistent orientations that are significant. For this, at least four independent fault solutions are needed (Angelier and Goguel, 1979; Sippel, 2009). Once stress fields are found these can be compared across several outcrops to identify large scale stress fields. All the data from one identified stress field are then included into one data set and the Multiple Inverse Method is used to determine if the inversion is accurate.

The Multiple Inverse Method (Yamaji, 2000) calculates the reduced stress tensor, i.e. the stress ratio of the principal stress axes, of all possible subsets of implemented faults with a minimum subset-size of 4 faults. This approach follows the Direct Inverse Method (Angelier, 1984) which determines the stress ratio by calculating the minimum misfit angle between the movement directions of a selected fault set. The basis for this approach is the Wallace-Bott theory, which states that slip along a plane occurs parallel to the direction of maximum resolved shear stress (Wallace, 1951; Bott, 1959).
The PBT-Method is conducted with the commercial software TectonicsFP (Reiter and Acs, 1996-2010), which further allows easy manual separation of fault clusters, and the Multiple Inverse Method with the open-source MIM Software Package of Yamaji and Sato (2005) where the separated fault clusters are implemented. A detailed description of the working process is given by Sippel et al. (2009).

In contrast to earlier methods (Sippel et al., 2009), we decided to merge the measurements of the single outcrops into one data set and use contour plots of the calculated principal stress axes to identify stress fields (Figs. 6b, 7). Merging the data has the advantages of minimizing the disturbance by local block rotation or tilting; reducing the risk of interpreting stresses induced by local fault or fracture interactions; and of reducing the influence of outcrop orientation. It further has the advantage of including single measurements in the larger scale stress analysis that might be regarded as insignificant in a single outcrop or sub-region analysis. Effects of lithology or basement structure variations on the spatial strain distribution are regarded as minimal, since no significant changes occur throughout the study areas. With this approach, local variations of stress fields are not easily detected, but contour plots of the whole data set allow us to identify stress fields that have affected the whole study area. A PBT-analysis of local subsets is presented as 

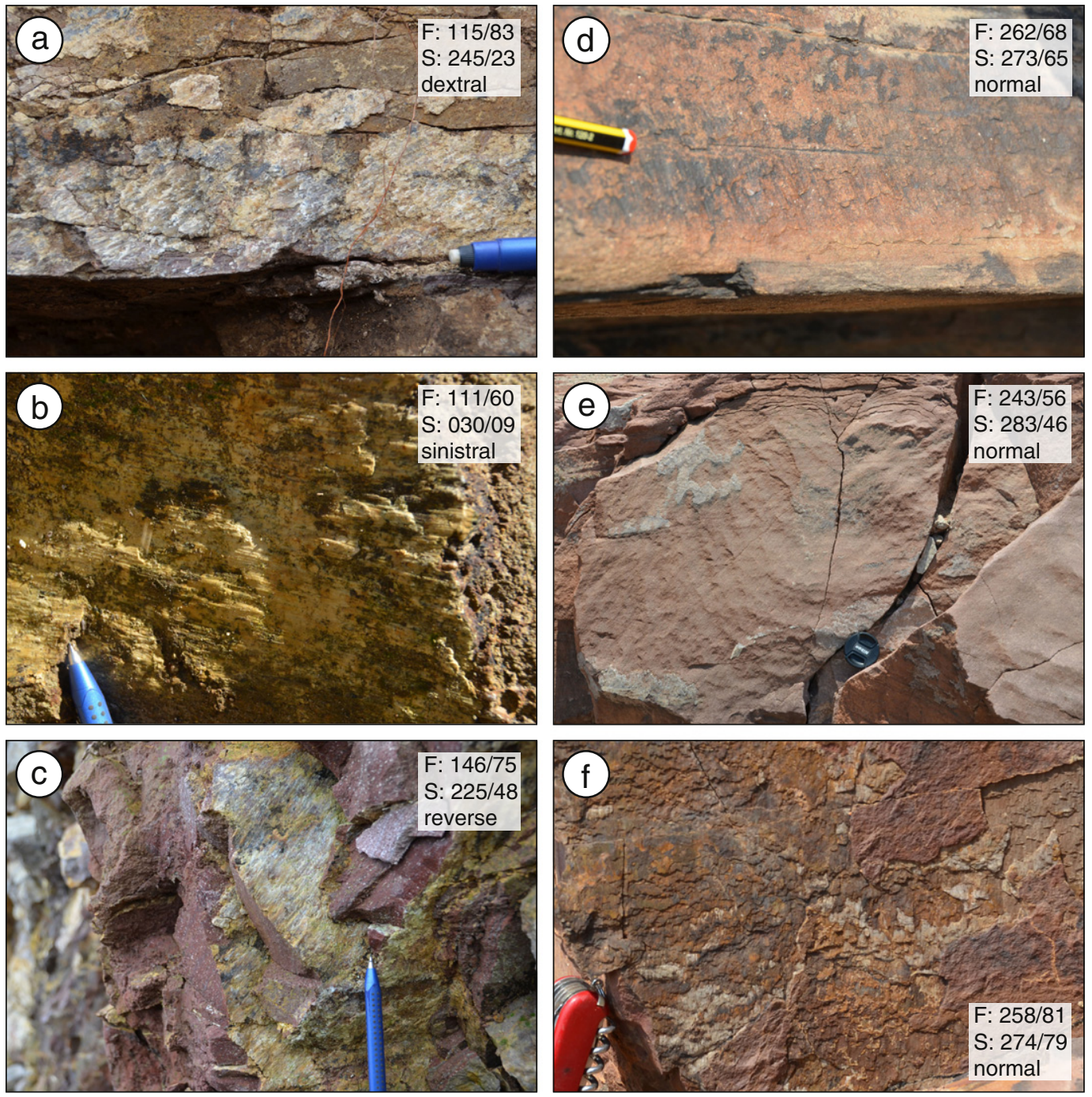

Fig. 5. Examples of fault slickensides found in the field with fault plane orientation (F), slickenside orientation (S) and shear sense. (a-c: Brazil; d-f: Namibia).

supplementary material (Figs. S1, S2). We decided only to select and analyze the most prominent stress concentration maxima seen in the contour plots.

\section{Results}

\subsection{Lineaments}

We mapped 359 lineaments in the Serra Geral volcanics in SE/S Brazil using satellite imagery provided by Google Earth and $30 \mathrm{~m}$ ASTER digital elevation models. An example of the lineaments is given in Fig. 3 and a rose diagram is used to show the overall trend of all measured lineaments (location of Fig. 3 shown in Fig. 2). In Brazil, a closely spaced set of lineaments striking ENE dominates the pattern completely. Two less pronounced sets exist with strikes around NE and NW. When the trend of the lineaments is compared to the geological map in Fig. 2, one can observe that a) most of the lineaments do not trend parallel to the margin and $b$ ) the main lineament trend is not parallel to basement shear zones (shown in light red in Fig. 2). Margin parallel lineaments may be expected if margin parallel faults or joints were formed. This does not seem to be the case in Brazil, or if such faults and joints exist they are only minor. The oblique trend of the lineaments with respect to basement shear zones may indicate that reactivation of these zones does not play a major role in the development of younger faults in the basalts. A small number of the lineaments have a trend that is parallel or subparallel to shear zones in the basement and might thus be indicative for reactivation of basement structures.

In Namibia, we mapped 832 lineaments in the Etendeka volcanics. A typical example of lineaments on the Etendeka plateau is presented in Fig. 4 and the trend of all lineaments is shown in a rose diagram in the upper left hand corner in Fig. 4. The majority of the lineaments strike N-S to NNW-SSE or NW-SE. A less pronounced set of lineaments strikes E-W. The satellite image presented in Fig. 4 shows three main trends, N-S strike, NW-SE strike and E-W strike. The position of Fig. 4 is indicated in the geological map in Fig. 2 where it becomes clear that a) the NW-SE trend of lineaments is parallel to the margin and $b$ ) the N-S trend is parallel to basement shear zones. In Namibia one can thus expect that margin parallel normal faults dominate the lineament pattern in combination with reactivation of shear zones in the basement. Only a minor E-W trend of lineaments is not compatible with this interpretation.

In summary, mapping of lineaments in SE/S Brazil and NW Namibia produces very different patterns for both continental margins indicating that they have different fault or fracture patterns and thus experienced different stress histories.

\subsection{Fault slip analysis}

We performed a fault slip analysis in order to unravel the stress fields of the two opposite continental margins. In Brazil, we collected 

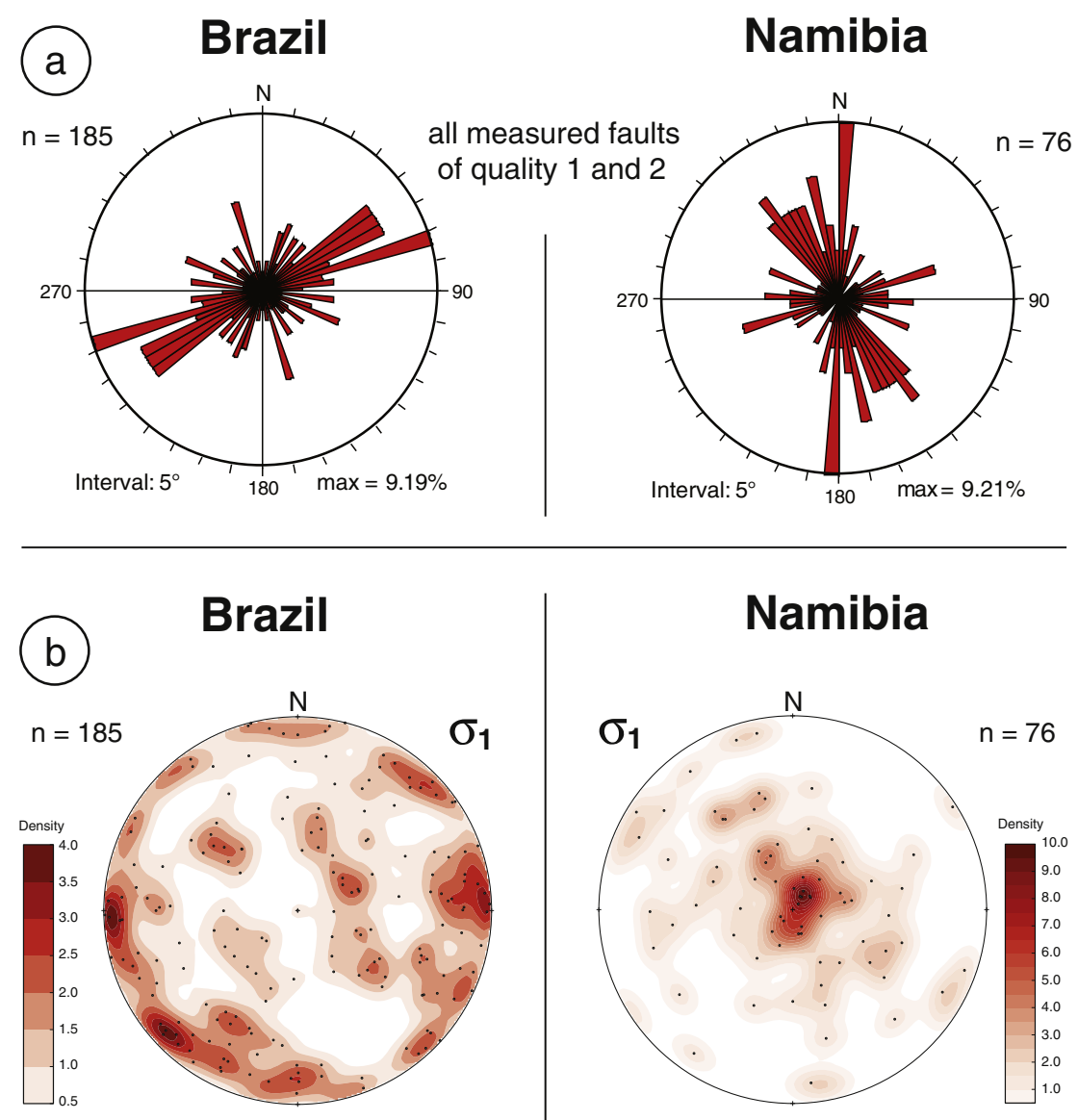

\section{Namibia}
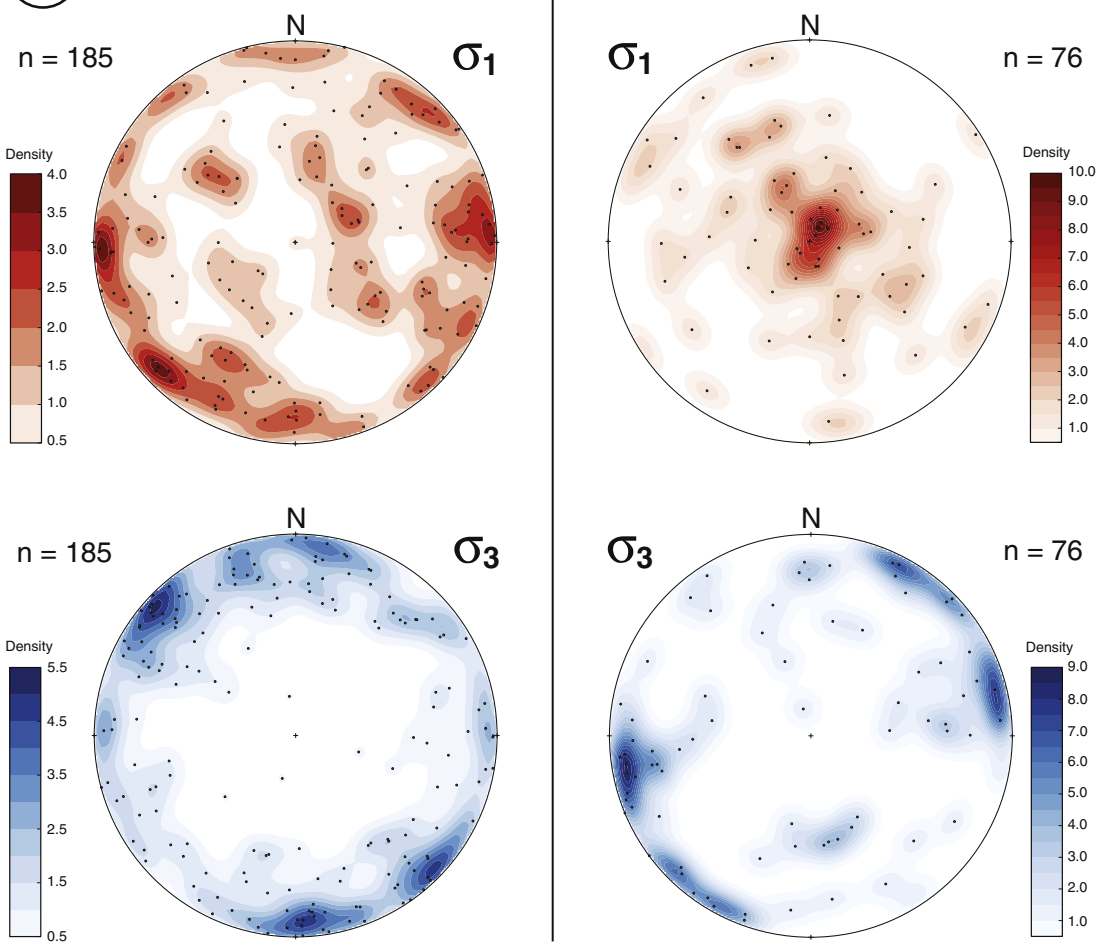

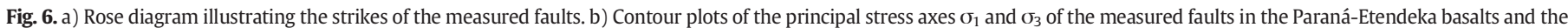

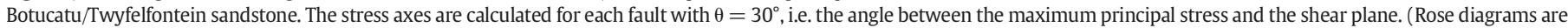
generated with TectonicsFP software of Reiter and Acs, 1996-2010, and contour plots with OpenStereo of Grohmann and Campanha, 2010.).

field data in 35 outcrops of the Serra Geral volcanics and the Botucatu Sandstone and obtained 185 measurements of quality 1 and 2 ("excellent" and "good") (see supplementary material for fault slip data and outcrop coordinates). Examples are shown in Fig. 5a-c. Only a few outcrops exhibited no faults or only bad quality data. Measurements in outcrops near mapped lineaments do not consistently show an orientation parallel to the respective lineament. Overall, however, the faults have approximately the same strike orientation as the mapped lineaments (e.g. orientation maxima lie within $5^{\circ}$ ) indicating that the latter might be produced by the faults (Figs. 3, 6a). The faults were then analyzed with the PBT-method that gives the orientation of the principal stresses for each single fault measurement. The combined results of all the orientations of the stress axis are shown as contour plots on the left hand side of Fig. $6 \mathrm{~b}$. Red contours are for the main compressive stress axes, $\sigma_{1}$, and blue contours for the smallest principal stress axes, $\sigma_{3}$. According to the Anderson principle, a vertical $\sigma_{1}$ and horizontal $\sigma_{3}$ indicate an extensional regime with normal faults, a horizontal $\sigma_{1}$ and a vertical $\sigma_{3}$ characterize a compressional regime with reverse faults, and a horizontal $\sigma_{1}$ and $\sigma_{3}$ are indicative of a compressional regime with strike-slip faults. Fig. 6b clearly shows, with the data from Brazil, that $\sigma_{3}$ is on the outside of the stereonet and thus horizontal with maxima indicating NW-SE and N-S trends. $\sigma_{1}$ shows a more complex distribution with several maxima on the outside of the stereonet indicating a horizontal $\sigma_{1}$ mainly in an E-W and a SW-NE direction and minor maxima with variable moderate dip orientations. Overall, the pattern is clearly dominated by strike-slip with two major trends, one with an E-W directed compression and the second with a SW-NE directed compression. In addition, a minor strike-slip regime with a N-S compression component may be present alongside minor extensional regimes with variable extension directions (Fig. 6b). The setting becomes clearer when we divide the study area into northern and southern parts (Fig. 7, dashed line in Fig. 2b). In the southern half, two strike-slip 


\section{Brazil, northern area}
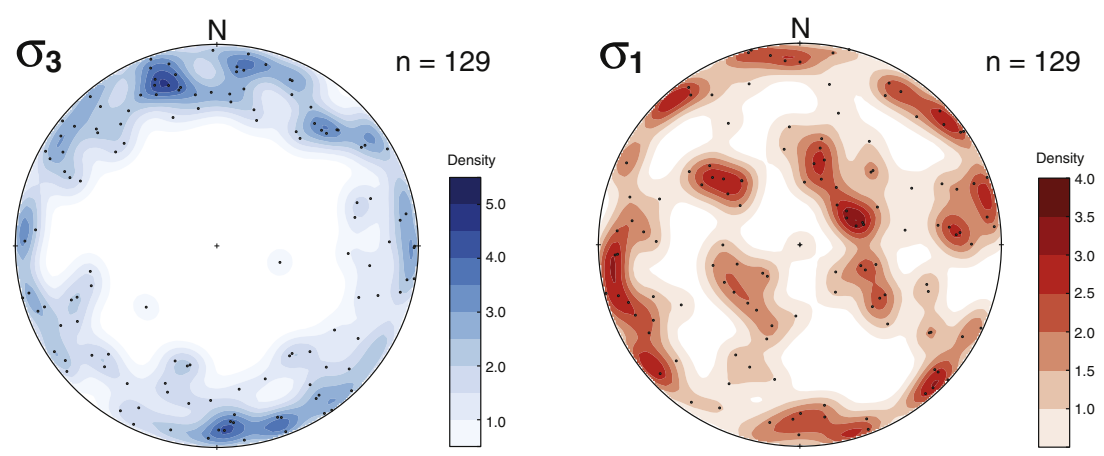

\section{Brazil, southern area}
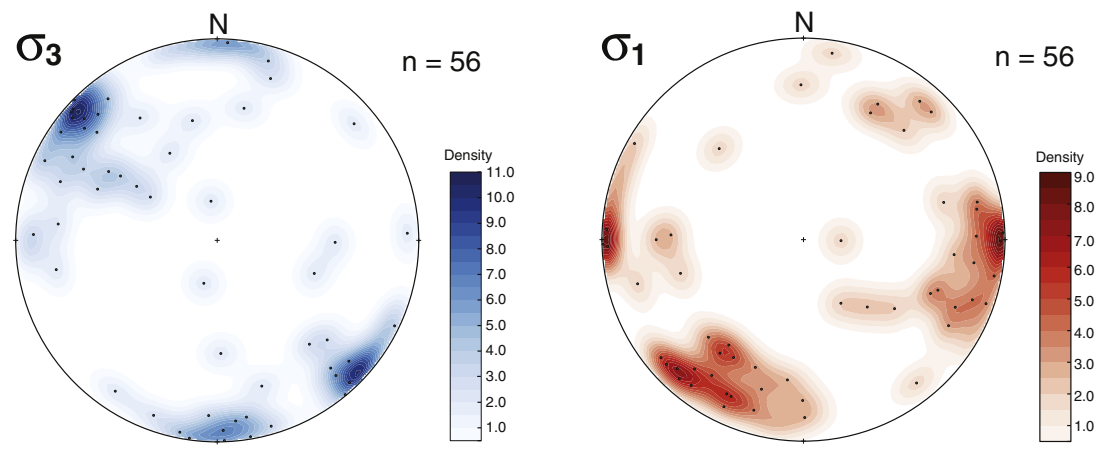

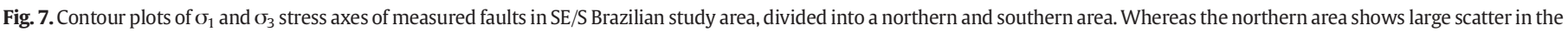

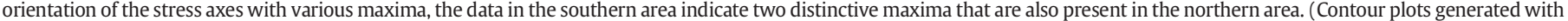
the software OpenStereo of Grohmann and Campanha, 2010.).

systems dominate with $\sigma_{1}$ oriented $\mathrm{SW}$ and $\mathrm{W}$. As these two systems also appear in the northern area, the focus of this study lies on them. The SW compressional strike-slip regime has a sinistral transpressional character $(\Phi=0.20$ ) with the south-eastern side moving upward along the ENE trending faults (Fig. 8). The strike-slip system with compression to the $\mathrm{W}$ affects the same fault system, yet in a dextral pure strike-slip regime $(\Phi=0.50)$. No cross-cutting relationships were found to relatively date the stress regimes of these two strike-slip systems. In conclusion, we see that the Brazilian margin is strike-slip dominated with faults that are not parallel to the margin and that the faults are unrelated to major reactivation of basement structures, since shear zone-parallel faults are rare. The northern part of our study area, towards the Ponta Grossa dyke swarm, shows more complex stress patterns indicating several possible extensional and strike-slip directions. The data are not good enough to separate these possible regimes with confidence. The fault dip data that do not fit into the calculated stress tensors are shown in Supplementary Fig. S3.

In Namibia, we collected 76 fault slip measurements in 26 outcrops in the Etendeka volcanics and the Twyfelfontein Sandstone that could be used for further processing. Examples are shown in Fig. 5d-f. A number of outcrops exhibited no faults or only bad quality. The local lithologies and large-scale geology are very similar to those in Brazil, but there is a relative scarcity of faults cropping out in Namibia, perhaps due to the different weathering and erosional history, or a less active tectonic history. As in Brazil, the strikes of the faults resemble the orientations of the lineaments (Figs. 4, 6a). The fault slip data set produces a steeply plunging $\sigma_{1}$ maximum and a sub-horizontal $\sigma_{3}$ (right hand side of Fig. $6 \mathrm{~b})$. The stress regime in Namibia seems to be mainly extensional with two main orientations of extension, in ENE-WSW and in SSWNNE direction.
28 measurements, i.e. $37 \%$ of the total considered data, indicate an extensional regime with $\sigma_{3}$ oriented ENE (Fig. 8). Most of the faults strike $\sim$ NNW, yet seven strike E to NE. Four of these are measured along basalt dykes, i.e. structures along which fault movement at a low shear-to-normal stress ratio is likely. A best-fit stress ratio is achieved with $\Phi=0.05$, showing radial extension (Fig. 8). A second extensional stress field is indicated by 8 measurements with faults striking $\sim \mathrm{NW}, \sigma_{3}$ oriented NNE and a stress ratio of $\Phi=0.20 .10$ fault slip measurements represent a strike-slip regime with compression to the NW and a stress ratio of $\Phi=0.60$, indicating a transtensional stress regime. Similar to Brazil, a relative timing of these three stress regimes cannot be obtained with our data set as no cross-cutting relationships were found. The fault dip data that do not fit into the calculated stress tensors are shown in Supplementary Fig. S3.

\section{Discussion}

\subsection{Differences between the two correlating continental margins}

The orientations of lineaments mapped on satellite imagery (Figs. 3, 4) differ markedly between the two correlating margins. In NW Namibia, the majority of lineaments trend parallel to the continentocean boundary, whereas in SE/S Brazil the dominant lineament orientation is rotated clockwise by $\sim 40^{\circ}$ from the continent-ocean boundary and only a minor set strikes parallel to the margin. In both study areas all lineament maxima are very similar to the orientation maxima of faults that were measured in the field (Figs. 3, 4, 6a). We can draw two conclusions from this similarity, a) the lineaments may be related to faults and b) the small-scale outcrop measurements are representative of large-scale trends. 

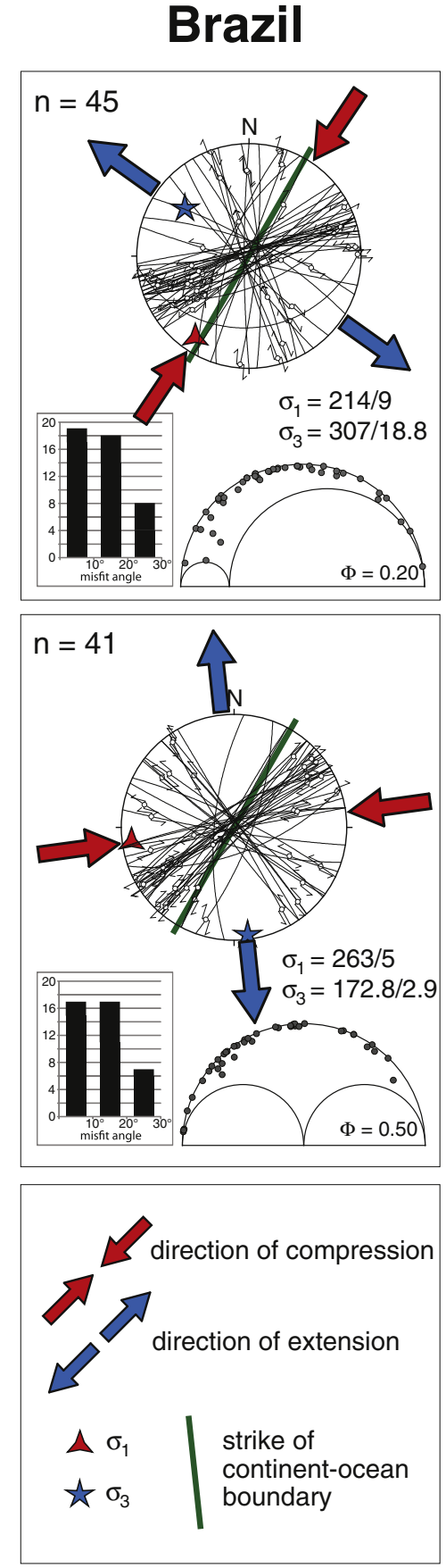

Namibia
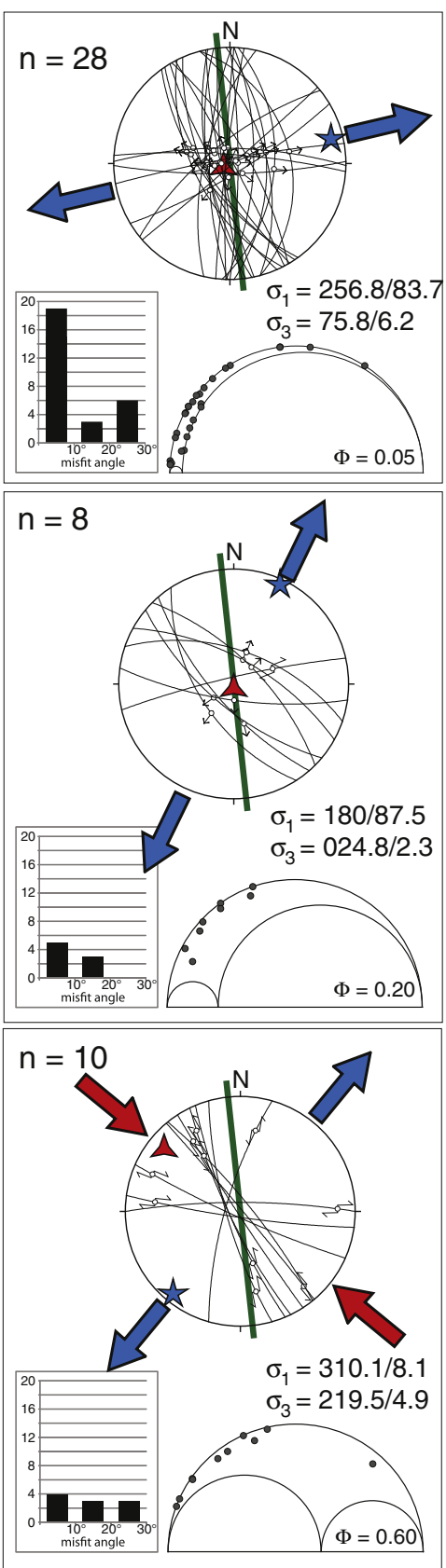

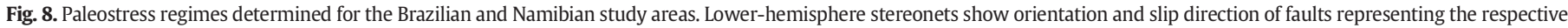

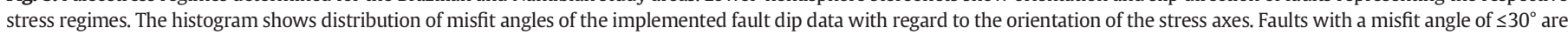

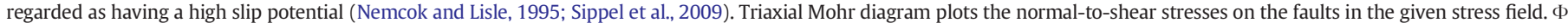
indicates the stress ratio of the principal stress axes (e.g. $\Phi$ is 0 if $\sigma_{1}>\sigma_{2}=\sigma_{3}$ or 1 if $\sigma_{1}=\sigma_{2}>\sigma_{3}$ ).

The fault slip data also show major differences between Namibia and Brazil (Fig. 8). NW Namibia is largely dominated by extension, while in $\mathrm{SE} / \mathrm{S}$ Brazil strike-slip dominates the kinematic regime. In Namibia, the largest data set forms an extensional stress regime with $\sigma_{3}$ oriented ENE, which is perpendicular to the continental margin and could therefore be the result of Atlantic rifting and later margin extension. A Mohrratio of $\Phi=0.05$ indicates a component of radial extension, which could be related to domal uplift above the Tristan da Cunha plume that was still present in this area during rifting (Turner et al., 1994). A second minor stress field in Namibia exhibits NE-SW extension, while a third minor stress field shows strike-slip with the compressional axis oriented NW-SE. It is not clear how important the last two stress regimes are on a larger continental scale. The three stress fields account for $61 \%$ of the data implying that the study area has experienced additional stresses. However as no clear stress pattern can be calculated from the remaining data, their origin is not interpreted here.

In SE/S Brazil, the stress pattern appears very different as two strikeslip systems dominate the study area, with their compressional axes oriented E-W and NE-SW (Fig. 8). Extensional faults related to the Atlantic rifting either do not exist onshore or are overprinted. Margin-parallel faults are scarce in our study area, indicating that rift-related faulting played a minor role onshore, reducing the likelihood of an overprinted extensional stress regime. Nonetheless, such a stress regime must have affected the margin, as documented by rift-related extensional 
faulting offshore (Blaich et al., 2011), so it seems likely the rift-related faulting was restricted to a narrow strip between the continent-ocean boundary and the present-day coastline. The prominent NW trending Ponta Grossa dyke swarm (Fig. 1), which was emplaced in the late phase of the Paraná volcanic extrusion and thus at times of rifting, indicates NE-directed extension, i.e. parallel to the margin. If this is also true for our study area $400 \mathrm{~km}$ south of the Ponta Grossa dyke swarm, this could explain the scarcity of margin parallel faults.

In addition to the two dominant strike-slip regimes, the number of paleostress tensors that can be extracted from the fault slip data of the northern and southern Brazilian study areas varies. While in the south, $63 \%$ of the data can be attributed to either the strike-slip stress regimes with compressional axis oriented E-W or NE-SW, in the north only $39 \%$ of the data fit into these two regimes. Due to the large scatter of the remaining $61 \%$ of data in the north, any separation of this data would have to be seen as highly speculative. However it is clear that the northern study area has experienced a far more complex stress evolution than the southern one. The scatter seems unlikely to be related to inheritance of Precambrian basement structures, as Neoproterozoic shear zones in the basement seem to strike NE throughout the study area (Passarelli et al., 2011), a direction appearing only subdued in the younger fault pattern.

What other reasons may produce the complicated stress patterns in the northern part of our Brazilian study area? Reconstruction of the breakup history of South America and Africa is confronted by several misfits of the conjugated continental margins, which are resolved by implementing major fault systems across the continents which accommodate the deformation necessary to reconstruct the ocean margins (e.g., Nürnberg and Müller, 1991; König and Jokat, 2006; Eagles, 2007; Torsvik et al., 2009; Moulin et al., 2010). One of these fault systems is placed as a major transform fault on the Brazilian side extending from the Florianopolis Fracture Zone in the South Atlantic through the whole continent to the Pacific margin (compare for example Fig. 24 of Moulin et al., 2010, and Fig. 5 of Torsvik et al., 2009). If this fault or larger scale deformation zone exists, it runs straight through the northern part of our study area. A structure of such extent would be prone to frequent reactivation (Franco-Magalhaes et al., 2010; Karl et al., 2013) and could explain the complex fault slip data obtained in this area. Indeed, our data might serve as an indicator for the existence of a major fault system. However, aside from the Florianopolis Fracture Zone, a more evident factor is the appearance of the upper Cretaceous Lages Intrusion close to the northern edge of the study area (Fig. 2). It is shown that magmatic intrusions and later inflation of magmatic bodies disturb the regional stress field and induce local stress fields. Examples are found at Mount St. Helens (Lehto et al., 2010), at La Réunion (Chaput et al., 2014), or in the northern Canadian Shield (Hou et al., 2010). Anderson (1937) and Gudmundsson (2006) modeled how the principal stress axes are oriented around an intrusive body. In addition, analogue modeling has shown that magma chambers disturb the pattern of regional deformation (Montanari et al., 2010). One effect of an intrusion is rotation of the principal stress axes away from vertical and horizontal plunges to intermediate plunge angles. The emplacement of the Lages Intrusion should also have affected the local stress system and could therefore have contributed to the scattering of fault-slip data in the northern part of the Brazilian study area: it may for example have produced the $\sim 30^{\circ}-70^{\circ}$ dip angles of $\sigma_{1}$ (upper right rose diagram in Fig. 7).

The minor inversion of the NE-trending basement structure in SE/S Brazil contrasts with much stronger basement inversion further north between São Paulo and Rio de Janeiro (Fig. 1), where shear zones of the Ribeira Belt trend ENE-WSW, in an approximately $20^{\circ}$ clockwise deviation from directions in SE/S Brazil. In the Ribeira Belt, Cenozoic reactivation of old shear zones is well documented (Cogné et al., 2011, 2013), which implies that a change of $\sim 20^{\circ}$ in strike is sufficient for such structures to be reactivated. In further contrast to SE/S Brazil, evidence for shear zone reactivation is clearly seen in NW Namibia. This is suggested by Marsh et al. (2001) and Stanistreet and Charlesworth
(2001) and is hinted at by the increased concentration of faults directly along shear zones (Fig. 2c) and the overall parallelism of mapped shear zones to the measured faults in the field (Fig. 6a).

\subsection{Comparison with other Brazilian stress data}

Several paleostress studies have been conducted in the greater area of SE/S Brazil (e.g., Riccomini, 1995; Fernandes and Amaral, 2002; Strugale et al., 2007; Machado et al., 2012; Fig. 9). All of these studies, which are also mainly based on analyzing fault slip data, conclude on the presence of strike-slip systems dating from Cretaceous to present times. Some of these regimes have approximately the same orientation as our two main strike-slip regimes and these are summarized in a chronographic chart in Fig. 9. Based on these studies, the NE-SW compressional strike-slip regime falls into a time frame ranging from the Upper Cretaceous to at least the Paleocene and possibly to the Oligocene. Although more speculative, the E-W compressional strike-slip regime might have affected the passive margin during the Neogene to present.

In general, strike-slip faulting is prominent along the Brazilian passive margin. In the near-coastal region of NE Brazil, present strike-slip faulting with an E-W compressional axis is well known, as indicated by seismic data and borehole breakouts (e.g., Lima et al., 1997; Bezerra et al., 2011; Reis et al., 2013). As the compressional axis trends approximately parallel to the coast and the extensional axis perpendicular to it this pattern is explained as an effect of flexural bending of the continent-ocean transition, where cooling of the oceanic crust and sediment loading leads to subsidence offshore and uplift onshore (e.g., Assumpção, 1998; Ferreira et al., 1998). Assumpção et al. (2011) suggested the same mechanism to also affect the SE Brazilian margin based on a study of earthquakes offshore there. Indeed, the strike-slip system with NW-SE extension observed in SE Brazil (Fig. 8) is associated with a lowest principal stress that is oriented approximately coast-perpendicular and could thus derive from flexural bending. However, an additional compressive force has to be active to produce strike-slip faulting. Further, flexural bending cannot explain the second strike-slip system with compression perpendicular to the margin.

Further effects that are discussed to influence the passive margin are ridge push related to the South Atlantic mid-ocean ridge and basal drag of mantle flowing underneath the tectonic plates. To what degree these forces influence intraplate stresses is debated (e.g., Richardson, 1992; Coblentz and Richardson, 1996; Steinberger et al., 2001; Hirsch et al., 2010; Husson et al., 2012; Green et al., 2013). Whereas ridge push is directed away from the mid-Atlantic ridge, the direction of basal drag is controlled by mantle flow patterns that do not necessarily align with spreading axes (Savage, 1999). For the South Atlantic, it is argued that asthenospheric flow is directed from underneath southern Africa towards South America as response to the upwelling of the African superplume (Behn et al., 2004; Forte et al., 2010; Husson et al., 2012; Colli et al., 2013). Along the Brazilian margin, recent stress systems have been attributed to partly derive from these forces. The orientation of strike-slip systems along the NE Brazilian margin has been suggested as the combined result of flexural bending and ridge push or basal drag (Assumpção, 1992). Further, Assumpção (1998) relates earthquake offshore SE Brazil with reverse focal mechanism to the same combined effect, although Assumpção et al. (2011) makes primarily flexural stresses along the shelf responsible for the seismicity. Similarly, Japsen et al. (2012b) argue for ridge push having only a subdued effect on a Campanian uplift phase of the NE Brazilian margin as it coincides with a decline of the Atlantic spreading rate, which would rather result in a decrease of ridge push. With respect to our study area, it is not clear to which degree ridge push and basal drag shall result in NE-SW directed horizontal compression, i.e. margin-parallel compression, or contribute to a change to E-W directed horizontal compression. Still, even though regional variations of orientation occur along the Brazilian margin, the combined 


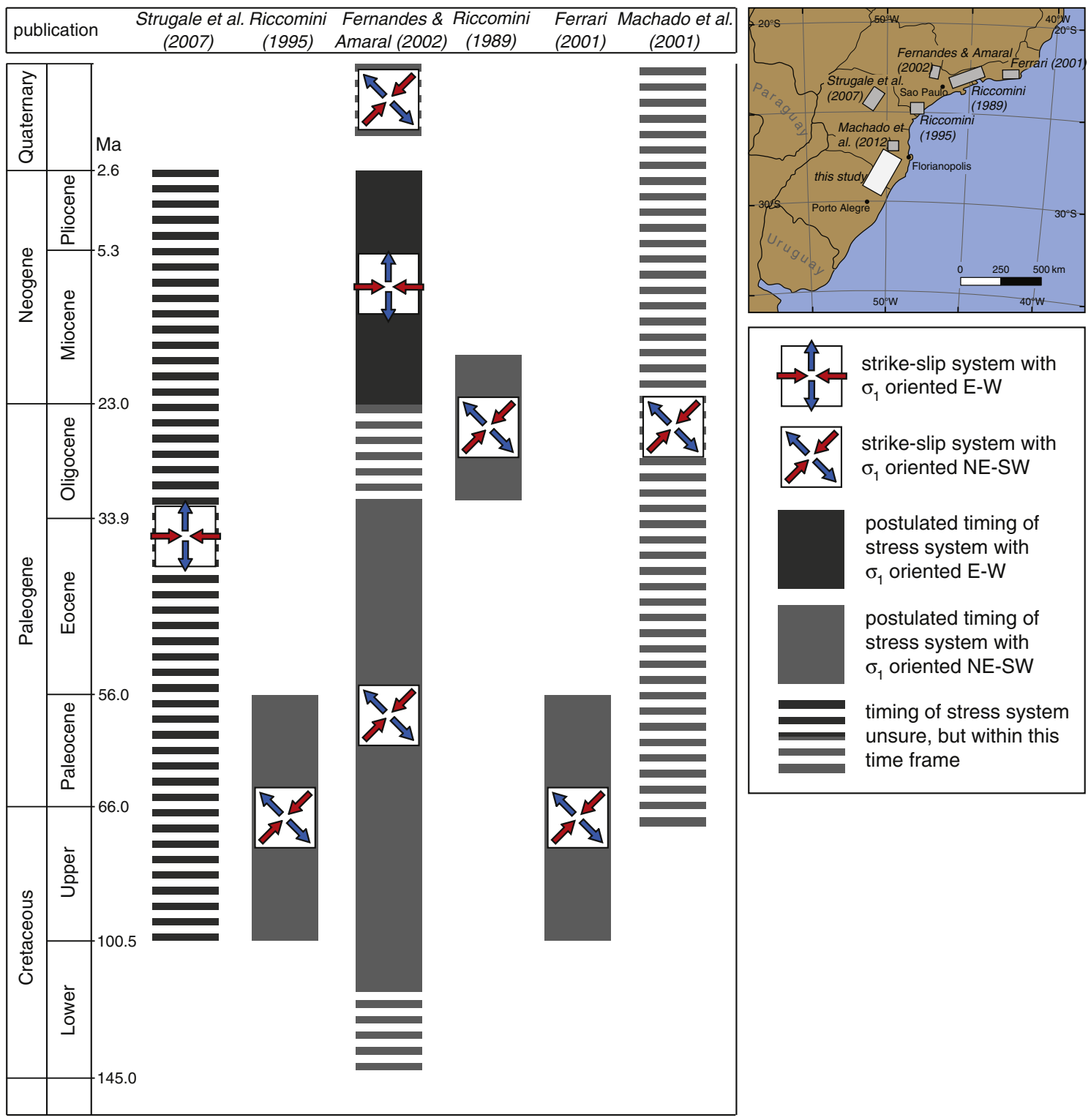

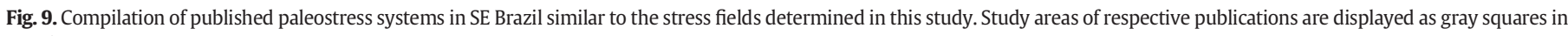
map inset.

forces of ridge push and basal drag on the eastern side of the continent, and the subduction on its western side may result in the observed overall strike-slip fault regime as suggested and modeled by others (e.g., Coblentz and Richardson, 1996; Cobbold et al., 2007; Husson et al., 2012).

An aspect that could explain the observed change of strike-slip systems in SE Brazil through time is the changing subduction direction of the Nazca plate underneath South America: Cobbold et al. (2001, 2007) relate the NE-SW and E-W compression in SE Brazil to the subduction direction, which was NE directed between 47 and $28 \mathrm{Ma}$ and ENE directed from 25 Ma to present (Somoza and Ghidella, 2012), slightly overlapping with the respective compressive stress axis of the strike-slip regimes in SE/S Brazil (Fig. 9). However, major uplift of the Andes started approximately at the beginning of the Miocene (Maloney et al., 2013, and references therein), which indicates that the NE directed subduction has not resulted in significant compression of the continent. This Miocene uplift however coincides well with the E-W directed strike-slip system observed by Fernandes and Amaral (2002; Fig. 9) and Neogene E-W compression suggested by Cogné et al. (2013) for the Taubaté basin between São Paulo and Rio de Janeiro.
The recent $M_{w} 8.8$ Maule earthquake in Chile in 2010 resulted in coseismic displacement across the continent with movements of up to $6 \mathrm{~mm}$ at the east-Brazilian coast (Vigny et al., 2012), indicating that stress can be transferred across a whole continent. In addition, S/SE Brazil is at about the same latitude as the flat-slab subduction section of the Nazca Plate underneath South America $\left(27^{\circ} 00^{\prime} \mathrm{S}-33^{\circ} 30^{\prime} \mathrm{S}\right.$; e.g., Ramos et al., 2002), which is generally made responsible for the uplift of the Sierras Pampeanas in central Argentina, $600-800 \mathrm{~km}$ east of the trench (e.g., Jordan et al., 1983). The flat-slab subduction started around 18-12 Ma which coincides with the uplift of the Sierra Pampeanas starting at around $8 \mathrm{Ma}$ (Ramos et al., 2002). This implies that the eastwards directed flat-slab subduction transmitted stresses further into the continent than normal-angle subduction did before and thus was more likely to influence the SE/S Brazilian margin. These observations, i.e. the displacement during the Maule earthquake and deformation propagation since the flat-slab subduction, lead us to conclude that the observed E-W compressional strike slip system in the SE/ $\mathrm{S}$ derives from the subduction zone.

In summary, the observed strike-slip system with NE-SW directed compression and NW-SE directed extension, i.e. margin perpendicular, 
could be the combined result of flexural bending, which causes marginperpendicular extension, and subduction of the Nazca plate, ridge push and basal drag, which lead to a general compressive setting. The effect of flexural bending is later superposed by $\mathrm{E}-\mathrm{W}$ compression deriving from the accelerated Andean uplift in the Neogene.

\subsection{Comparison with other South African stress data}

There are significant differences between our paleostress data and paleostress regimes published for SW South Africa (Viola et al., 2012). In Namaqualand (Fig. 1), Viola et al. (2012) identified two compressional events younger than $90 \mathrm{Ma}$ (their D7 and D9) indicated by a significant number of fault slip data, whereas the extensional stress field related to the opening of the South Atlantic appears subdued with only a small number of fault slip data. Yet again, rift-related extension is observed in the Saldania Belt near Cape Town by Will and Frimmel (2013) (Fig. 1). One can explain the scarcity of extensional faults related to the South Atlantic opening in Viola et al.'s (2012) data by the great distance $(\sim 350 \mathrm{~km})$ of their study area from the continental margin. In contrast, our study area is about $200 \mathrm{~km}$ from the continent-ocean boundary and the study area of Will and Frimmel (2013) is even closer to it. Extensional faulting in Africa is known to be restricted to rift zones that may be between $100 \mathrm{~km}$ and $300 \mathrm{~km}$ wide (Morley, 1999).

Our second extensional stress field with a NE-SW directed extension direction might correspond to that responsible for D8 of Viola et al. (2012) as both the extension directions and stress ratios ( $\Phi=0.20$ of our stress field and 0.25 of D8) are similar. D8 is related to a NE-SW extensional phase that is postulated to have affected the whole African continent in the Campanian-Maastrichtian (Guiraud and Bosworth, 1997). The basis for this postulation is a number of $\sim \mathrm{N}-\mathrm{NW}$ trending rifts of that age in northern and northern-central Africa and along the southern African margin during this time (Fig. 29 in Guiraud and Bosworth, 1997). However, the assigned rift event in the Orange Basin offshore western South Africa is now considered to be a gravitational margin failure induced by punctuated margin uplift and thermal subsidence (de Vera et al., 2010). We are therefore cautious of linking the NE-SW extensional stress system to an African wide Campanian-Maastrichtian extension phase.

As flexural bending of the lithosphere due to sediment loading offshore is considered a mechanism affecting the Brazilian margin, the same mechanism should be considered for the African margin. The Walvis and Orange basins, offshore and to the SW of the Namibian study area and western South Africa, accumulated significant amounts of sediments (Miller, 2008, and references therein) and flexural bending along the onshore margin of NW Namibia and elsewhere along the African margin due to sediment load may be significant (Dauteuil et al., 2013). Flexural bending would result in margin perpendicular extension related to our NE-SW extensional stress field, and equally contribute to the most pronounced E-W extensional stress tensor, which we primarily assign to the South Atlantic rifting. To what extent our data reflects the Albian rift offshore NW Namibia, described as a local tectonic event by Holtar and Forsberg (2000), is unclear.

The compressional events in the data of Viola et al. (2012; their D7 and D9) are not easy to correlate with our stress data. Our strike-slip system may represent the present-day stress field, as the compressional axis has a similar orientation as the present-day maximum horizontal compression in southwest Africa (Viola et al., 2005; Heidbach et al., 2008), but might also correlate to the D7 event of Viola et al. (2012). Viola et al. (2012) link both their D7 and D9 to compression that is evident in northern and central Africa during the Late Santonian and Late Maastrichtian, respectively (Guiraud and Bosworth, 1997; Bosworth et al., 1999). The Late Santonian compression is related to "the first general compressional episode registered by the African-Arabian plate during the Alpine Cycle" (Guiraud et al., 2005) and also the Late Maastrichtian event is related to counterclockwise rotational northward drift of Africa-Arabia into Eurasia (Guiraud and Bosworth, 1997). If we assume that Viola et al. are correct in concluding that far-field stresses are responsible for compression in Namaqualand, the question arises why this compression is not expressed in NW Namibia. Our data show only a minor set of reverse faults and in addition, both events are not observed in the $\sim$ E-W striking Lufilian Arc in southern Congo (Fig. 1; Kipata et al., 2013). The effects of possible far-field compression should be similar or even better developed in north-western Namibia or southern Congo, because both areas lie closer to the source of transmitted stress, i.e. northern Africa. We therefore suggest the option that regional compressional stress fields existed, which are responsible for the observed compression in southern Africa, for Late Cretaceous rock and surface uplift in the Damara Belt in central Namibia (Raab et al., 2002) and for post-Eocene rock and surface uplift in South Africa (Japsen et al., 2012a).

Regarding local variations of the stress fields, we need to consider the geometry of the Neoproterozoic basement structure and its influence on younger structures. The Kaoko Belt, which underlies the Etendeka basalts, is dominated by an approximately N-S trending foliation (e.g., Passchier et al., 2002; Goscombe and Gray, 2008) whereas in the Damara Belt, south of the study area, foliation and lineaments trend about ENE-WSW (e.g., Kisters et al., 2004; Corner, 2008). As foliation surfaces are prone to reactivation as faults, N-S directed compression would more likely produce thrust faults in the Damara Belt than in the Kaoko Belt. Reverse faulting along ENE trending faults is indeed observed in Late Tertiary calcretes near the town of Omaruru in the Damara belt (Klein, 1980). Strong basement control on rift-related extension is also argued by Will and Frimmel (2013) who analyzed dykes and faults along the southern African margin from Cape Town to Angola. This implies that southern Africa reacts highly heterogeneously to the application of far-field stresses, as also proposed by others (e.g., Janssen et al., 1995; Ziegler et al., 1995). A detailed paleostress study in the Damara Belt might help to resolve this matter, because in this case paleostress tensors in the Damara Belt should be very different than in the nearby Kaoko Belt.

Upwelling of the African superplume, which is thought to have led to the high topography of southern Africa and associated widespread rock and surface uplift (e.g., Nyblade and Robinson, 1994; Gurnis et al., 2000; Flament et al., 2014), should result in overall extensional stress regimes in southern Africa as it stretches the crust, a mechanism generally outlined by Hafner (1951). The African superplume is inferred to have remained unchanged in size and position for the last $300 \mathrm{Ma}$ (Burke et al., 2008) with the African continent riding over it after the breakup of Gondwana (Braun et al., 2014). Another model to explain the high topography is introduced by Moore et al. (2009) who link circumferential drainage divides in southern Africa to reorganizations of oceanic spreading axes which induced compressive stresses to the continent. However, neither model fits the paleostress data well. Compression derived from oceanic spreading ridges, i.e. ridge push, should result in margin-perpendicular compressive stress, which is not observed by Viola et al. (2012) and Will and Frimmel (2013) or our study. On the other hand, an influence of the African superplume is hard to combine with the compressive stress regimes outlined by Viola et al. (2012). This indicates that these effects may play at most a supporting role in the stress history of southern Africa.

In summary, varying paleostress data in southern Africa may be the result of regional stress variations or a heterogeneous deformation that is controlled by the basement structure. Ridge push from the Atlantic spreading axis seems not to exert a strong control on the margin as no margin-perpendicular compression is observed. The overall extensional regime in NW Namibia may derive from flexural bending due to sediment loading offshore and the continuous uplift of the African superplume. 


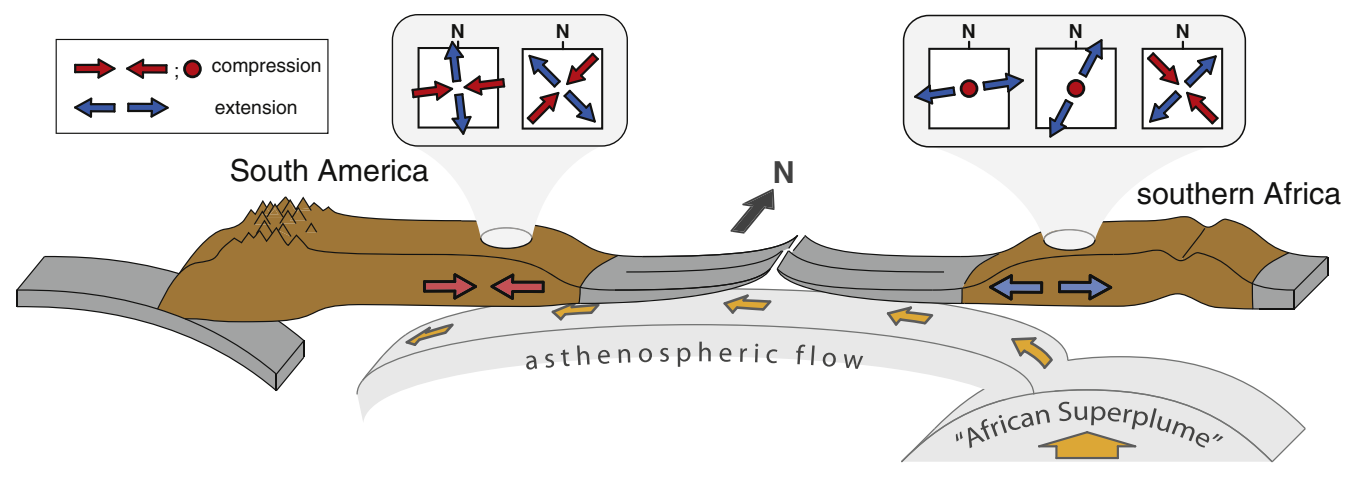

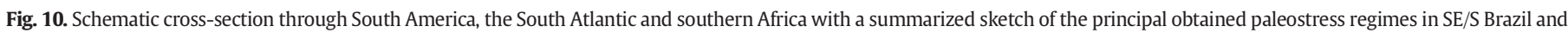

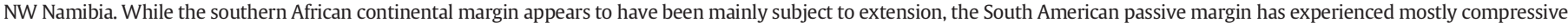

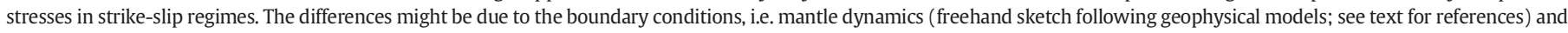
the subduction zone along the west of South America.

\section{Conclusions}

Paleostress analysis on two originally adjacent areas of the South Atlantic, SE/S Brazil and NW Namibia shows that lineament trends, fault patterns, stress regimes and basement reactivation have been significantly different on both sides of the South Atlantic since its opening. NW Namibia has experienced mostly extension related to the Atlantic rifting and flexural bending of the margin, whereas SE/S Brazil has experienced compressional stresses resulting in two major strike-slip regimes with compression parallel and at a high angle to the margin (Fig. 10). In Brazil, our results are in good agreement with other paleostress studies, which depict similar strike-slip systems, indicating that a large part of the passive margin was subject to strike-slip faulting. The strike-slip regime with compression parallel to the continental margin might be the combined result of flexural bending of the margin and stress transmitted from NE directed subduction of the Nazca plate in the Paleogene. This stress system is later overprinted by the E-W compressional strike-slip regime resulting from the Andean uplift and the flat-slab subduction in the Neogene. For both study areas, we regard an influence of ridge push from the Atlantic mid-ocean ridge as subdued, because no margin-perpendicular compression is observed in the study areas.

Paleostress studies are scarce along the southern African passive margin, but it appears that stress regimes are more variable. The available data may indicate that margin parallel extension is restricted to a zone less than $350 \mathrm{~km}$ wide along the ocean continent boundary. Reactivation of basement shear zones is common in NW Namibia with shear zones striking sub-parallel to the orientation of normal faults. In SE/S Brazil, reactivation is either absent or plays a minor role since most shear zones are not oriented in a favorable position for reactivation during strike-slip, in contrast to significant reactivation of shear zones during the formation of the Cenozoic continental rift system further north between São Paulo and Rio de Janeiro.

The overall difference between a normal faulting-dominated margin in Namibia and a strike-slip faulting-dominated margin in Brazil could be rooted in the different boundary conditions that the continents experience. Africa is influenced by continental rifting and the African superswell with a significant vertical uplift and local scale extension at the margin, whereas South America may be entirely under compression due to the subduction on the continent's western side and a westward asthenospheric flow beneath the South Atlantic.

\section{Acknowledgments}

We thank the Geological Survey of Namibia and the Palmvag Lodge for permission to work in the ecologically sensitive areas of NW Namibia. Furthermore, we thank Sebastian Wex and João Paulo de Cortes for their assistance during field work, Giulio Viola and Marco
Andreoli for discussions and Francisco Bezerra for helpful thoughts. Constructive reviews by Graeme Eagles and Peter Cobbold are gratefully acknowledged. This project was funded by the German Research Foundation (DFG; grant no. KO 2463/8-1) within the priority program SAMPLE (South Atlantic Margin Processes and Links with Onshore Evolution; SPP 1375). The Schürmann Foundation is thanked for several grants to CP for field expenses.

\section{Appendix A. Supplementary data}

The measured minor faults near a very prominent $\mathrm{N}-\mathrm{S}$ trending normal fault with large-scale down-faulting to the west, in the center of our NW Namibian study area, supports our approach of merging the data. Despite the clear extension direction of the fault, fault slip data obtained near this fault indicate a broadly N-S extension (encircled white in Supplementary Fig. S2). This shows that it is not self-evident that the data of local subsets resolves even prominent faulting events nearby. However, the overall image of the merged data resolves the $\mathrm{E}-\mathrm{W}$ extension (Fig. 6b). Supplementary data to this article can be found online at http://dx.doi.org/10.1016/j.gr.2014.09.006.

\section{References}

Al-Hajri, Y., White, N., Fishwick, S., 2009. Scales of transient convective support beneath Africa. Geology 37, 883-886.

Anderson, E.M. 1937. The dynamics of the formation of cone sheets, ring dykes, and cauldron subsidences. Proceedings of the Royal Society of Edinburgh 56, 128-157.

Angelier, J., 1984. Tectonic analysis of fault slip data sets. Journal of Geophysical Research 89, 5835-5848.

Angelier, J., Goguel, J., 1979. Sur une méthode simple de détermination des axes principaux des contraintes pour une population de failles. Comptes rendus de l'Académie des Sciences de Paris (D) 288, 307-310.

Assumpção, M., 1992. The regional intraplate stress field in South America. Journal of Geophysical Research - Solid Earth 97, 11889-11903.

Assumpção, M., 1998. Focal mechanisms of small earthquakes in the southeastern Brazilian shield: a test of stress models of the South American plate. Geophysical Journal International 133, 490-498.

Assumpção, M., Dourado, J.C., Ribotta, L.C., Mohriak, W.U., Dias, F.L., Barbosa, J.R., 2011 The Sao Vicente earthquake of 2008 April and seismicity in the continental shelf off SE Brazil: further evidence for flexural stresses. Geophysical Journal International $187,1076-1088$

Bauer, K., Neben, S., Schreckenberger, B., Emmermann, R., Hinz, K., Fechner, N., Gohl, K. Schulze, A., Trumbull, R.B., Weber, K., 2000. Deep structure of the Namibia continental margin as derived from integrated geophysical studies. Journal of Geophysical Research - Solid Earth 105, 25829-25853.

Beglinger, S.E., Doust, H., Cloetingh, S., 2012. Relating petroleum system and play development to basin evolution: Brazilian South Atlantic margin. Petroleum Geoscience 18 315-336.

Behn, M.D., Conrad, C.P., Silver, P.G., 2004. Detection of upper mantle flow associated with the African superplume. Earth and Planetary Science Letters 224, 259-274.

Bezerra, F.H.R., do Nascimento, A.F., Ferreira, J.M., Nogueira, F.C., Fuck, R.A., Brito Neves, B.B., Sousa, M.O.L., 2011. Review of active faults in the Borborema Province, Intraplate South America - integration of seismological and paleoseismological data. Tectonophysics 510, 269-290. 
Blaich, O.A., Faleide, J.I., Tsikalas, F., 2011. Crustal breakup and continent-ocean transition at South Atlantic conjugate margins. Journal of Geophysical Research - Solid Earth 116,38

Bonow, J.M., Japsen, P., Lidmar-Bergstrom, K., Chalmers, J.A., Pedersen, A.K., 2006. Cenozoic uplift of Nuussuaq and Disko, West Greenland - elevated erosion surfaces as uplift markers of a passive margin. Geomorphology 80, 325-337.

Bosworth, W., Guiraud, R., Kessler, L.G., 1999. Late Cretaceous (ca. 84 Ma) compressive deformation of the stable platform of northeast Africa (Egypt): far-field stress effects of the "Santonian event" and origin of the Syrian arc deformation belt. Geology 27 633-636.

Bott, M.H.P., 1959. The mechanics of oblique slip faulting. Geological Magazine 96, 109-117.

Braun, J., Guillocheau, F., Robin, C., Baby, G., Jelsma, 2014. Eroding a large continental area by tilting it over a source of mantle upwelling to explain the late Cretaceous South African erosional event. Geophysical Research Abstracts 16 (EGU2014-4219).

Burke, K., Steinberger, B., Torsvik, T.H., Smethurst, M.A., 2008. Plume generation zones at the margins of large low shear velocity provinces on the core-mantle boundary. Earth and Planetary Science Letters 265, 49-60.

Byerlee, J.D., 1968. Brittle-ductile transition in rocks. Journal of Geophysical Research 73, 4741-4750.

Channell, J.E.T., Erba, E., Nakanashi, M., Tamaki, K., 1995. Late Jurassic-Early Cretaceous time scales and oceanic magnetic anomaly block models. In: Berggren, W.A., et al. (Eds.), Geochronology, Time Scales, and Global Stratigraphic Correlation. SEPM Special Publication 54, pp. 51-63 (Society for Sedimentary Geology, Tulsa, Oklahoma).

Chaput, M., Famin, V., Michon, L., 2014. Deformation of basaltic shield volcanoes under cointrusive stress permutations. Journal of Geophysical Research - Solid Earth 119, 274-301.

Chemale Jr., F., Mallmann, G., Bitencourt, M.d.F., Kawashita, K., 2012. Time constraints on magmatism along the Major Gercino Shear Zone, southern Brazil: implications for West Gondwana reconstruction. Gondwana Research 22, 184-199.

Cobbold, P.R., Meisling, K.E., Mount, V.S., 2001. Reactivation of an obliquely rifted margin, Campos and Santos basins, southeastern Brazil. AAPG Bulletin 85, 1925-1944.

Cobbold, P.R., Rossello, E.A., Roperch, P., 2007. Distribution, timing, and causes of Andean deformation across South America. Deformation of the continental crust: the legacy of Mike Coward. Geological Society, London, Special Publications $272,321-343$.

Coblentz, D.D., Richardson, R.M., 1996. Analysis of the South American intraplate stress field. Journal of Geophysical Research - Solid Earth 101, 8643-8657.

Cogné, N., Gallagher, K., Cobbold, P.R., 2011. Post-rift reactivation of the onshore margin of southeast Brazil: evidence from apatite (U-Th)/He and fission-track data. Earth and Planetary Science Letters 309, 118-130.

Cogné, N., Cobbold, P.R., Riccomini, C., Gallagher, K., 2013. Tectonic setting of the Taubate Basin (Southeastern Brazil): insights from regional seismic profiles and outcrop data. Journal of South American Earth Sciences 42, 194-204.

Colli, L., Fichtner, A., Bunge, H.-P., 2013. Full waveform tomography of the upper mantle in the South Atlantic region: imaging a westward fluxing shallow asthenosphere? Tectonophysics $604,26-40$

Corner, B., 2008. Crustal framework of Namibia derived from an integrated interpretation of geophysical and geological data. In: Miller, R.McG. (Ed.), The Geology of Namibia. Ministry of Mines and Energy, Geological Survey of Namibia, Windhoek (pp. 2-1-19).

Dauteuil, O., Deschamps, F., Bourgeois, O., Mocquet, A., Guillocheau, F., 2013. Post-breakup evolution and palaeotopography of the North Namibian Margin during the MesoCenozoic. Tectonophysics 589, 103-115.

de Vera, J., Granado, P., McClay, K., 2010. Structural evolution of the Orange Basin gravitydriven system, offshore Namibia. Marine and Petroleum Geology 27, 223-237.

de Wit, M.J., Jeffery, M., Bergh, H., Nicolayson, L.O., 1988. Explanation to geological map of sectors of Gondwana. American Associaion of Petroleum Geologists, Tulsa.

de Wit, M.J., Stankiewicz, J., Reeves, C., 2008. Restoring Pan-African-Brasiliano connections: more Gondwana control, less Trans-Atlantic corruption. Geological Society, London, Special Publications 294, 399-412.

Deckart, K., Féraud, G., Marques, L.S., Bertrand, H., 1998. New time constraints on dyke swarms related to the Paraná-Etendeka magmatic province, and subsequent South Atlantic opening, southeastern Brazil. Journal of Volcanology and Geothermal Research 80, 67-83.

Dentzien-Dias, P.C., Schultz, C.L., Scherer, M.S.C., Lavina, E.L.C., 2007. The trace fossil record from the Guará Formation (Upper Jurassic), southern Brazil. Arquivos do Museu Nacional, Rio de Janeiro 64, 585-600.

Eagles, G., 2007. New angles on South Atlantic opening. Geophysical Journal Internationa $168,353-361$

Erlank, A.J., Marsh, J.S., Duncan, A.R., Miller, R.M., Hawkesworth, C.J., Betton, P.J., Rex, D.C. 1984. Geochemistry and petrogenesis of the Etendeka volcanic rocks from SWA Namibia. Geological Society of South Africa, Special Publications 13, 195-245.

Fernandes, A.J., Amaral, G., 2002. Cenozoic tectonic events at the border of the Parana Basin, São Paulo, Brazil. Journal of South American Earth Sciences 14, 911-931.

Ferrari, A.L., 2001. Evolução Tectônica do Graben da Guanabara(PhD thesis) Instituto de Geociências da Universidade de São Paulo, p. 412.

Ferreira, J.M., Oliveira, R.T., Takeya, M.K., Assumpção, M., 1998. Superposition of local and regional stresses in northeast Brazil: evidence from focal mechanisms around the Potiguar marginal basin. Geophysical Journal International 134, 341-355.

Flament, N., Gurnis, M., Williams, S., Seton, M., Skogseid, J., Heine, C., Müller, R.D., 2014 Topographic asymmetry of the South Atlantic from global models of mantle flow and lithospheric stretching. Earth and Planetary Science Letters 387, 107-119.

Forte, A.M., Quéré, S., Moucha, R., Simmons, N.A., Grand, S.P., Mitrovica, J.X., Rowley, D.B., 2010. Joint seismic-geodynamic-mineral physical modelling of African geodynamics: a reconciliation of deep-mantle convection with surface geophysical constraints. Earth and Planetary Science Letters 295, 329-341.
Foster, D.A., Goscombe, B.D., Gray, D.R., 2009. Rapid exhumation of deep crust in an obliquely convergent orogen: The Kaoko Belt of the Damara Orogen. Tectonics 28, TC4002. http://dx.doi.org/10.1029/2008TC002317.

Franco-Magalhaes, A.O.B., Hackspacher, P.C., Glasmacher, U.A., Saad, A.R., 2010. Rift to post-rift evolution of a "passive" continental margin: the Ponta Grossa Arch, SE Brazil. International Journal of Earth Sciences 99, 1599-1613.

Gallagher, K., Hawkesworth, C., 1994. Mantle plumes, continental magmatism and asymmetry in the South Atlantic. Earth and Planetary Science Letters 123, 105-117.

Gibson, S.A., Thompson, R.N., Leonardos, O.H., Dickin, A.P., Mitchell, J.G., 1999. The limited extent of plume-lithosphere interactions during continental flood-basalt genesis: geochemical evidence from Cretaceous magmatism in southern Brazil. Contributions to Mineralogy and Petrology 137, 147-169.

Gladczenko, T.P., Hinz, K., Eldholm, O., Meyer, H., Neben, S., Skogseid, J., 1997. South Atlantic volcanic margins. Journal of the Geological Society 154, 465-470.

Goscombe, B.D., Gray, D.R., 2008. Structure and strain variation at mid-crustal levels in a transpressional orogen: a review of Kaoko Belt structure and the character of West Gondwana amalgamation and dispersal. Gondwana Research 13, 45-85.

Goscombe, B., Gray, D., Armstrong, R., Foster, D.A., Vogl, J., 2005. Event geochronology of the Pan-African Kaoko Belt, Namibia. Precambrian Research 140, 103-131.

Gradstein, F.M., Ogg, J.G., Smith, A.G., 2004. A Geologic Time Scale 2004. Cambridge University Press, Cambridge (589 pp.)

Green, P.F., Lidmar-Bergstrom, K., Japsen, P., Bonow, J.M., Chalmers, J.A., 2013. Stratigraphic landscape analysis, thermochronology and the episodic development of elevated, passive continental margins. Geological Survey of Denmark and Greenland Bulletin 30, 9-150.

Grohmann, C.H., Campanha, G.A.C., 2010. OpenStereo: open source, cross-platform software for structural geology analysis. AGU Fall Meeting 2010 (\#IN31C-06)

Gudmundsson, A., 2006. How local stresses control magma-chamber ruptures, dyke injections, and eruptions in composite volcanoes. Earth-Science Reviews 79, 1-31.

Guiraud, R., Bosworth, W., 1997. Senonian basin inversion and rejuvenation of rifting in Africa and Arabia: synthesis and implications to plate-scale tectonics. Tectonophysics $282,39-82$

Guiraud, R., Bosworth, W., Thierry, J., Delplanque, A., 2005. Phanerozoic geological evolution of Northern and Central Africa: an overview. Journal of African Earth Sciences 43, 83-143.

Gurnis, M., Mitrovica, J.X., Ritsema, J., van Heijst, H.J., 2000. Constraining mantle density structure using geological evidence of surface uplift rates: the case of the African superplume. Geochemistry, Geophysics, Geosystems 1, 1020. http://dx.doi.org/10. 1029/1999GC000035.

Hafner, W., 1951. Stress distributions and faulting. Geological Society of America Bulletin $62,373-398$

Handin, J., 1966. Section 10: strength and ductility. In: Clark Jr., S.P. (Ed.), Handbook of Physical Constants. Geological Society of America Memoirs 97, pp. 223-290 (Geological Society of America, New York).

Hartmann, L.A., da Cunha Duarte, L., Massonne, H.-J., Michelin, C., Rosenstengel, L.M., Bergmann, M., Theye, T., Pertille, J., Arena, K.R., Duarte, S.K., Pinto, V.M., Barboza, E.G., Rosa, M.L.C.C., Wildner, W., 2012. Sequential opening and filling of cavities forming vesicles, amygdales and giant amethyst geodes in lavas from the southern Paraná volcanic province, Brazil and Uruguay. International Geology Review $54,1-14$

Heidbach, O., Tingay, M., Barth, A., Reinecker, J., Kurfeß, D., Müller, B., 2008. The World Stress Map database release 2008. http://dx.doi.org/10.1594/GFZ.WSM.Rel2008.

Heine, C., Zoethout, J., Müller, R.D., 2013. Kinematics of the South Atlantic rift. Solid Earth Discussion 5, 41-115. http://dx.doi.org/10.5194/sed-5-41-2013.

Hirsch, K.K., Scheck-Wenderoth, M., van Wees, J.-D., Kuhlmann, G., Paton, D.A., 2010. Tectonic subsidence history and thermal evolution of the Orange Basin. Marine and Petroleum Geology 27, 565-584.

Holtar, E., Forsberg, A.W., 2000. Postrift development of the Walvis Basin, Namibia: results from the exploration campaign in Quadrant 1911. In: Mello, M.R., Katz, B.J. (Eds.), Petroleum Systems of South Atlantic Margins. AAPG Memoir 73, pp. 429-446.

Hou, G., Kusky, T.M., Wang, C., Wang, Y., 2010. Mechanics of the giant radiating Mackenzie dyke swarm: a paleostress field modeling. Journal of Geophysical Research Solid Earth 115, B02402. http://dx.doi.org/10.1029/2007JB005475.

Husson, L., Conrad, C.P., Faccenna, C., 2012. Plate motions, Andean orogeny, and volcanism above the South Atlantic convection cell. Earth and Planetary Science Letters 317, 126-135.

Janssen, M.E., Stephenson, R.A., Cloetingh, S., 1995. Temporal and spatial correlations between changes in plate motions and the evolution of rifted basins in Africa. Geological Society of America Bulletin 107, 1317-1332

Japsen, P., Chalmers, J.A., Green, P.F. Bonow, J.M., 2012a. Elevated, passive continental margins: not rift shoulders, but expressions of episodic, post-rift burial and exhumation. Global and Planetary Change 90-91, 73-86.

Japsen, P., Bonow, J.M., Green, P.F., Cobbold, P.R., Chiossi, D., Lilletveit, R., Magnavita, L.P., Pedreira, A., 2012b. Episodic burial and exhumation in NE Brazil after opening of the South Atlantic. Geological Society of America Bulletin 124, 800-816.

Jerram, D., Mountney, N., Holzforster, F., Stollhofen, H., 1999. Internal stratigraphic relationships in the Etendeka Group in the Huab Basin, NW Namibia: understanding the onset of flood volcanism. Journal of Geodynamics 28, 393-418.

Jordan, T.E., Isacks, B.L., Allmendinger, R.W., Brewer, J.A., Ramos, V.A., Ando, C.J., 1983. Andean tectonics related to geometry of subducted Nazca plate. Geological Society of America Bulletin 94, 341-361.

Karl, M., Glasmacher, U.A., Kollenz, S., Franco-Magalhaes, A.O.B., Stockli, D.F., Hackspacher, P.C., 2013. Evolution of the South Atlantic passive continental margin in southern Brazil derived from zircon and apatite $(\mathrm{U}-\mathrm{Th}-\mathrm{Sm}) / \mathrm{He}$ and fission-track data. Tectonophysics 604, 224-244. 
Kipata, M.L., Delvaux, D., Sebagenzi, M.N., Cailteux, J., Sintubin, M., 2013. Brittle tectonic and stress field evolution in the Pan-African Lufilian arc and its foreland (Katanga, DRC): from orogenic compression to extensional collapse, transpressional inversion and transition to rifting. Geologica Belgica 16 (1-2), 1-17.

Kisters, A.F.M., Jordaan, L.S., Neumaier, K., 2004. Thrust-related dome structures in the Karibib district and the origin of orthogonal fabric domains in the south Central Zone of the Pan-African Damara belt, Namibia. Precambrian Research 133, 283-303.

Klein, J.A., 1980. Pleistocene to Recent faulting in the area west of Omaruru (SWA/Namibia), Regional Geology Series Open File Report RG 4, p. 28

König, M., Jokat, W., 2006. The Mesozoic breakup of the Weddell Sea. Journal of Geophysical Research - Solid Earth 111, B12102. http://dx.doi.org/10.1029/ 2005JB004035.

Lehto, H.L., Roman, D.C., Moran, S.C., 2010. Temporal changes in stress preceding the 2004-2008 eruption of Mount St Helens, Washington. Journal of Volcanology and Geothermal Research 198, 129-142.

Lima, C., Nascimento, E., Assumpção, M., 1997. Stress orientations in Brazilian sedimentary basins from breakout analysis: implications for force models in the South American plate. Geophysical Journal International 130, 112-124.

Lithgow-Bertelloni, C., Silver, P.G., 1998. Dynamic topography, plate driving forces and the African superswell. Nature 395, 269-272.

Machado, R., Roldan, L.F., Jacques, P.D., Fassbinder, E., Nummer, A.R., 2012. Tectônica transcorrente Mesozoica-Cenozoica no Domo de Lages-Santa Catarina. Revista Brasileira de Geociencias 42, 799-811.

Malinverno, A., Hildebrandt, J., Tominaga, M., Channell, J.E.T., 2012. M-sequence geomagnetic polarity time scale (MHTC12) that steadies global spreading rates and incorporates astrochronology constraints. Journal of Geophysical Research - Solid Earth 117, B06104. http://dx.doi.org/10.1029/2012JB009260.

Maloney, K.T., Clarke, G.L., Klepeis, K.A., Quevedo, L., 2013. The Late Jurassic to present evolution of the Andean margin: drivers and the geological record. Tectonics 32, 1049-1065. http://dx.doi.org/10.1002/tect.20067.

Marsh, J.S., Ewart, A., Milner, S.C., Duncan, A.R., Miller, R.M., 2001. The Etendeka Igneous Province: magma types and their stratigraphic distribution with implications for the evolution of the Paraná-Etendeka flood basalt province. Bulletin of Volcanology 62, 464-486.

McKenzie, D., 1978. Some remarks on development of sedimentary basins. Earth and Planetary Science Letters 40, 25-32.

Meisling, K.E., Cobbold, P.R., Mount, V.S., 2001. Segmentation of an obliquely rifted margin, Campos and Santos basins, southeastern Brazil. AAPG Bulletin 85, 1903-1924.

Melfi, A.J.P., Piccirillo, E.M., Nardy, A.J.R., 1988. Geological and magmatic aspects of the Paraná Basin: an introduction. In: Piccirillo, E.M., Melfi, A.J. (Eds.), The Mesozoic Flood Volcanism of the Paraná Basin: Petrogenetic and Geophysical Aspects. Universidade de São Paulo, Instituto Astronômico e Geofísico, São Paulo, pp. 1-14.

Miller, R.M.G., 2008. The Geology of Namibia, Ministry of Mines and Energy. Geological Survey of Namibia, Windhoek

Milner, S.C., Duncan, A.R., 1987. Geochemical characterisation of quartz latite units in the Etendeka Formation. Communications of the Geological Survey of Namibia 3, 83-90.

Milner, S.C., Ewart, A., 1989. The geology of the Goboboseb Mountain volcanics and their relationship to the Messum Complex, Namibia. Communications of the Geological Survey of Namibia 5, 31-40.

Milner, S.C., Duncan, A.R., Ewart, A., 1992. Quartz latite rheoignimbrite flows of the Etendeka formation, north-western Namibia. Bulletin of Volcanology 54, 200-219.

Milner, S.C., Duncan, A.R., Whittingham, A.M., Ewart, A., 1995. Trans-Atlantic correlation of eruptive sequences and individual silicic volcanic units within the ParanáEtendeka igneous province. Journal of Volcanology and Geothermal Research 69, 137-157.

Montanari, D., Corti, G., Simakin, A., 2010. Magma chambers and localization of deformation during thrusting. Terra Nova 22, 390-395. http://dx.doi.org/10.1111/j.13653121.2010.00962.x

Moore, A., Blenkinsop, T., Cotterill, F., 2009. Southern African topography and erosion history: plumes or plate tectonics? Terra Nova 21, 310-315. http://dx.doi.org/10.1111/j. 1365-3121.2009.00887.x.

Morley, C.K., 1999. Geoscience of rift systems - evolution of East Africa. AAPG Studies in Geology Series no. 44, (The American Association of Petroleum Geologists, Tulsa).

Moucha, R., Forte, A.M., 2011. Changes in African topography driven by mantle convection. Nature Geoscience 4, 707-712.

Moulin, M., Aslanian, D., Unternehr, P., 2010. A new starting point for the South and Equatorial Atlantic Ocean. Earth-Science Reviews 98, 1-37.

Mountney, N., Howell, A., 2000. Aeolian architecture, bedform climbing and preservation space in the Cretaceous Etjo Formation, NW Namibia. Sedimentology 47, 825-849.

Nemcok, M., Lisle, R.J., 1995. A stress inversion procedure for polyphase fault/slip data sets. Journal of Structural Geology 17, 1445-1453.

Nürnberg, D., Müller, R.D., 1991. The tectonic evolution of the South-Atlantic from Late Jurassic to present. Tectonophysics 191, 27-53.

Nyblade, A.A., Robinson, S.W., 1994. The African superswell. Geophysical Research Letters $21,765-768$.

Oyhantçabal, P., Siegesmund, S., Wemmer, K., Passchier, C.W., 2011. The transpressional connection between Dom Feliciano and Kaoko Belts at 580-550 Ma. International Journal of Earth Sciences 100, 379-390.

Passarelli, C.R., Basei, M.A.S., Wemmer, K., Siga Jr., O., Oyhantçabal, P., 2011. Major shear zones of southern Brazil and Uruguay: escape tectonics in the eastern border of Rio de La plata and Paranapanema cratons during the Western Gondwana amalgamation. International Journal of Earth Sciences 100, 391-414.

Passchier, C.W., Trouw, R.A.J., Ribeiro, A., Paciullo, F.V.P., 2002. Tectonic evolution of the southern Kaoko belt, Namibia. Journal of African Earth Sciences 35, 61-75.
Peate, D.W., Hawkesworth, C.J., Mantovani, M.S.M., Shukowsky, W., 1990. Mantle plumes and flood-basalt stratigraphy in the Paraná, South-America. Geology 18, 1223-1226.

Perea, D., Soto, M., Veroslavsky, G., Martínez, S., Ubilla, M., 2009. A Late Jurassic fossi assemblage in Gondwana: biostratigraphy and correlations of the Tacuarembó Formation, Parana Basin, Uruguay. Journal of South American Earth Sciences 28, 168-179.

Piccirillo, E.M., Bellieni, G., Cavazzini, G., Comin-Chiaramonti, P., Petrini, R., Melfi, A.J., Pinese, J.P.P., Zantadeschi, P., De Min, A., 1990. Lower Cretaceous tholeiitic dyke swarms from the Ponta Grossa Arch (southeast Brazil): petrology, Sr-Nd isotopes and genetic relationships with the Paraná flood volcanics. Chemical Geology 89 19-48.

Raab, M.J., Brown, R.W., Gallagher, K., Carter, A., Weber, K., 2002. Late Cretaceous reactivation of major crustal shear zones in northern Namibia: constraints from apatite fission track analysis. Tectonophysics 349, 75-92.

Rabinowitz, P.D., Labrecque, J., 1979. The Mesozoic South Atlantic Ocean and evolution of its continental margins. Journal of Geophysical Research 84, 5973-6002.

Ramos, V.A., Cristallini, E.O., Pérez, D.J., 2002. The Pampean flat-slab of the Central Andes. Journal of South American Earth Sciences 15, 59-78.

Reis, Á.F.C., Bezerra, F.H.R., Ferreira, J.M., do Nascimento, A.F., Lima, C.C., 2013. Stress magnitude and orientation in the Potiguar Basin, Brazil: implications on faulting style and reactivation. Journal of Geophysical Research - Solid Earth 118. http://dx.doi.org/10. 1002/2012jb009953 (2012JB009953).

Reiter, F., Acs, P., 1996-2010. Tectonics FP - a computer program for structural geology http://www.tectonicsfp.com.

Renne, P.R., Ernesto, M., Pacca, I.G., Coe, R.S., Glen, J.M., Prévot, M., Perrin, M., 1992. The age of Paraná flood volcanism, rifting of Gondwanaland, and the JurassicCretaceous boundary. Science 258, 975-979.

Renne, P.R., Deckart, K., Ernesto, M., Féraud, G., Piccirillo, E.M., 1996. Age of the Ponta Grossa dike swarm (Brazil), and implications to Paraná flood volcanism. Earth and Planetary Science Letters 144, 199-211.

Riccomini, C., 1989. O Rift Continental do sudeste do Brasil(PhD. thesis) Institute of Geosciences, University of São Paulo, Brazil.

Riccomini, C., 1995. Padrão de fraturamentos do Maciço Alcalino de Cananéia, Estado de São Paulo: relações com a tectônica mesozóico-cenozóica do sudeste do Brasil. Revista Brasileira de Geociencias 25, 79-84.

Richardson, R.M., 1992. Ridge forces, absolute plate motions, and the intraplate stress field. Journal of Geophysical Research - Solid Earth 97, 11739-11748.

Ritsema, J., Deuss, A., van Heijst, H.J., Woodhouse, J.H., 2011. S40RTS: a degree-40 shearvelocity model for the mantle from new Rayleigh wave dispersion, teleseismic traveltime and normal-mode splitting function measurements. Geophysical Journal International 184, 1223-1236.

Savage, M.K., 1999. Seismic anisotropy and mantle deformation: what have we learned from shear wave splitting? Reviews of Geophysics 37, 65-106.

Scherer, C.M.S., 2000. Eolian dunes of the Botucatu Formation (Cretaceous) in southernmost Brazil: morphology and origin. Sedimentary Geology 137, 63-84.

Serviço Geológico do Brasil, 2006. Mapa Geodiversidade do Brasil, escala 1:2.500.000.

Sippel, J., 2009. The paleostress history of the Central European basin system. Scientific Technical Report; 09/06. Deutsches GeoForschungsZentrum GFZ.

Sippel, J., Scheck-Wenderoth, M., Reicherter, K., Mazur, S., 2009. Paleostress states at the south-western margin of the Central European Basin System - application of faultslip analysis to unravel a polyphase deformation pattern. Tectonophysics 470 129-146.

Smith, R.M.H., Eriksson, P.G., Botha, W.J., 1993. A review of the stratigraphy and sedimentary environment of the Karoo-aged basins of southern Africa. Journal of African Earth Sciences 16, 143-169.

Somoza, R., Ghidella, M.E., 2012. Late Cretaceous to recent plate motions in western South America revisited. Earth and Planetary Science Letters 331, 152-163.

Sperner, B., Zweigel, P., 2010. A plea for more caution in fault-slip analysis. Tectonophysics 482, 29-41.

Sperner, B., Ratschbacher, L., Ott, R., 1993. Fault-striae analysis - a turbo pascal program package for graphical presentation and reduced stress tensor calculation. Computers \& Geosciences 19, 1361-1388.

Stanistreet, I.G., Charlesworth, E.G., 2001. Damaran basement-cored fold nappes incorporating pre-collisional basins, Kaoko Belt, Namibia, and controls on Mesozoic supercontinental break-up. South African Journal of Geology 104, 1-12.

Steinberger, B., Schmeling, H., Marquart, G., 2001. Large-scale lithospheric stress field and topography induced by global mantle circulation. Earth and Planetary Science Letters 186, 75-91.

Stica, J.M., Zalán, P.V., Ferrari, A.L., 2014. The evolution of rifting on the volcanic margin of the Pelotas Basin and the contextualization of the Paraná-Etendeka LIP in the separation of Gondwana in the South Atlantic. Marine and Petroleum Geology 50, 1-21.

Stoker, M.S., Holford, S.P., Hillis, R.R., Green, P.F., Duddy, I.R., 2010. Cenozoic post-rift sedimentation off northwest Britain: recording the detritus of episodic uplift on a passive continental margin. Geology 38, 595-598.

Stollhofen, H., 1999. Karoo Synrift-Sedimentation und ihre tektonische Kontrolle am entstehenden Kontinentalrand Namibias. Zeitschrift der Deutschen Geologischen Gesellschaft 149, 519-632.

Strugale, M., Rostirolla, S.P., Mancini, F., Portela Filho, C.V., Fonseca Ferreira, F.J., de Freitas, R.C., 2007. Structural framework and Mesozoic-Cenozoic evolution of Ponta Grossa Arch, Paraná Basin, southern Brazil. Journal of South American Earth Sciences 24 203-227.

Tominaga, M., Sager, W.W., 2010. Revised Pacific M-anomaly geomagnetic polarity timescale. Geophysical Journal International 182, 203-232.

Torsvik, T.H., Rousse, S., Labails, C., Smethurst, M.A., 2009. A new scheme for the opening of the South Atlantic Ocean and the dissection of an Aptian salt basin. Geophysical Journal International 177, 1315-1333. 
Turner, F.J., 1953. Nature and dynamic interpretation of deformation lamellae in calcite of 3 marbles. American Journal of Science 251, 276-298.

Turner, S., Regelous, M., Kelley, S., Hawkesworth, C., Mantovani, M., 1994. Magmatism and continental break-up in the South Atlantic: high precision ${ }^{40} \mathrm{Ar}-{ }^{39} \mathrm{Ar}$ geochronology. Earth and Planetary Science Letters 121, 333-348.

Twiss, R.J., Moores, E.M., 2007. Structural Geology, second ed. W. H. Freeman and Company, New York

Vigny, C., Socquet, A., Peyrat, S., Ruegg, J.C., Metois, M., Madariaga, R., Morvan, S., Lancieri, M., Lacassin, R., Campos, J., Carrizo, D., Bejar-Pizarro, M., Barrientos, S., Armijo, R. Aranda, C., Valderas-Bermejo, M.C., Ortega, I., Bondoux, F., Baize, S., Lyon-Caen, H., Pavez, A., Vilotte, J.P., Bevis, M., Brooks, B., Smalley, R., Parra, H., Baez, J.C., Blanco, M., Cimbaro, S., Kendrick, E., 2012. The $2010 \mathrm{M}_{\mathrm{w}} 8.8$ Maule megathrust earthquake of Central Chile, monitored by GPS. Science 332, 1417-1421.

Viola, G., Andreoli, M., Ben-Avraham, Z., Stengel, I., Reshef, M., 2005. Offshore mud volcanoes and onland faulting in southwestern Africa: neotectonic implications and constraints on the regional stress field. Earth and Planetary Science Letters 231, 147-160.

Viola, G., Kounov, A., Andreoli, M.A.G., Mattila, J., 2012. Brittle tectonic evolution along the western margin of South Africa: more than 500 Myr of continued reactivation. Tectonophysics 514, 93-114.
Waichel, B.L., de Lima, E.F., Viana, A.R., Scherer, C.M., Bueno, G.V., Dutra, G., 2012. Stratigraphy and volcanic facies architecture of the Torres Syncline, Southern Brazil, and its role in understanding the Paraná-Etendeka Continental Flood Basalt Province. Journal of Volcanology and Geothermal Research 215, 74-82.

Wallace, R.E., 1951. Geometry of shearing stress and relation of faulting. Journal of Geology 59, 118-130.

Will, T.M., Frimmel, H.E., 2013. The influence of inherited structures on dike emplacement during Gondwana breakup in southwestern Africa. The Journal of Geology 121, 455-474.

Yamaji, A., 2000. The multiple inverse method: a new technique to separate stresses from heterogeneous fault-slip data. Journal of Structural Geology 22, 441-452.

Yamaji, A., Sato, K., 2005. MI Viewer, Version 4.17. Division of Earth and Planetary Sciences, Kyoto University, Kyoto.

Ziegler, P.A., Cloetingh, S., van Wees, J.D., 1995. Dynamics of intra-plate compressional deformation: the Alpine foreland and other examples. Tectonophysics 252, 7-59. 